\title{
Cathepsin S: investigating an old player in lung disease pathogenesis, comorbidities, and potential therapeutics
}

\author{
Ryan Brown ${ }^{1 \dagger}$, Sridesh Nath ${ }^{2 \dagger}$, Alnardo Lora ${ }^{2}$, Ghassan Samaha², Ziyad Elgamal ${ }^{2}$, Ryan Kaiser ${ }^{2}$, Clifford Taggart $^{1}$, \\ Sinéad Weldon ${ }^{1}$ and Patrick Geraghty ${ }^{2,3^{*}}$ (D)
}

\begin{abstract}
Dysregulated expression and activity of cathepsin S (CTSS), a lysosomal protease and a member of the cysteine cathepsin protease family, is linked to the pathogenesis of multiple diseases, including a number of conditions affecting the lungs. Extracellular CTSS has potent elastase activity and by processing cytokines and host defense proteins, it also plays a role in the regulation of inflammation. CTSS has also been linked to G-coupled protein receptor activation and possesses an important intracellular role in major histocompatibility complex class II antigen presentation. Modulated CTSS activity is also associated with pulmonary disease comorbidities, such as cancer, cardiovascular disease, and diabetes. CTSS is expressed in a wide variety of immune cells and is biologically active at neutral pH. Herein, we review the significance of CTSS signaling in pulmonary diseases and associated comorbidities. We also discuss CTSS as a plausible therapeutic target and describe recent and current clinical trials examining CTSS inhibition as a means for treatment.
\end{abstract}

\section{Proteases in pulmonary diseases}

Research in the last 60 years has demonstrated that proteases are critical contributors to pulmonary disease pathophysiology. Initially known as protein-degrading enzymes with a restricted spectrum of substrates, recent studies have revealed that the diversity of protease substrates and biological effects triggered by their processing is vast $[1,2]$. Proteases are primarily known for their matrix degradation capabilities, but also play significant roles in other biological mechanisms such as angiogenesis, growth factor bioavailability, cytokine processing, receptor shedding and activation, as well as cellular processes including migration, proliferation, invasion, and

\footnotetext{
* Correspondence: Patrick.Geraghty@downstate.edu

${ }^{\dagger}$ Ryan Brown and Sridesh Nath share first authorship

2Division of Pulmonary \& Critical Care Medicine, Department of Medicine, State University of New York Downstate Medical Centre, Brooklyn, NY, USA

${ }^{3}$ Department of Cell Biology, State University of New York Downstate Medical Centre, Brooklyn, NY, USA

Full list of author information is available at the end of the article
}

survival [3]. Importantly, protease activity requires tight regulation, and disruption of the close interplay between proteases, substrates and inhibitors may contribute to the pathogenesis and progression of a variety of pulmonary diseases, including muco-inflammatory diseases such as cystic fibrosis (CF) and chronic obstructive pulmonary disease (COPD), idiopathic pulmonary fibrosis (IPF), as well as infection [4]. In pulmonary diseases with a high neutrophil burden such as $\mathrm{CF}$, a protease:antiprotease imbalance is frequently observed. The activity of proteases such as neutrophil elastase (NE) in the respiratory tract is regulated by antiproteases, such as $\alpha 1$-antitrypsin (A1AT) [5], secretory leukoprotease inhibitor (SLPI) [6] and elafin [7]. However, in diseases like CF, the antiproteases are overburdened by their cognate proteases and this imbalance can result in chronic airway inflammation, decreased mucociliary clearance, mucus obstruction, extracellular matrix (ECM) remodeling, increased susceptibility to infection and impaired immune responses [8]. 
Classically, NE was deemed the primary culprit in pulmonary disease pathogenesis, however, the contributions and importance of other proteases are now being recognized $[9,10]$. There are many families of proteases, including metalloproteinases (matrix metalloproteinases, adamalysins, or pappalysins), serine proteases (elastase, coagulation factors, plasmin, tissue plasminogen activator, urokinase plasminogen activator), and the cysteine proteases (such as cathepsins). In this review, we will focus on one cysteine protease in particular, cathepsin S (CTSS), and outline the research supporting its growing importance in pulmonary diseases and the potential of targeting of CTSS as a therapeutic option.

\section{CTSS expression, production and function}

CTSS plays a significant role in various intracellular and extracellular processes, including proteolysis [11] and major histocompatibility complex (MHC) class IImediated immune responses [12]. CTSS is one of $15 \mathrm{ca}-$ thepsin proteases encoded in the human genome that partake in various cellular processes [13-15]. They are categorized into three distinct protease subclasses determined by the enzyme's active site catalytic residue; cysteine (B, C, F, H, K, L, O, S, V, W and X), aspartic (D and $E$ ), and serine (A and G) proteases [2]. CTSS is one of 11 cysteine cathepsin proteases, which is the largest cathepsin subclass. Cathepsins B, C, F, H, L, O, and X are expressed ubiquitously in human tissues and cells [16]. However, cathepsins K, W, V, and S are localized to certain tissues or cells [2]. CTSS is mainly found inside the lysosomal/endosomal compartments of antigenpresenting cells, such as B cells, macrophages, dendritic cells, but is also produced by epithelial cells, smooth muscle cells, endothelial cells, and neutrophils [17-21].

\section{CTSS production, activation, and secretion}

The Ctss gene is found at the 1q21 chromosome in humans and, like all lysosomal cathepsins, is translated into a prepro-enzyme before being converted into a mature active state [22]. This acts as an important initial regulatory mechanism following the translation of the protein and during its localization to the lysosome [23]. Prepro-CTSS is composed of 331 amino acids [24] and contains three distinct domains; a signal domain, a propeptide domain, and a mature domain [22]. The secretion of CTSS usually occurs via vesicular exocytosis with elevated intracellular $\mathrm{Ca}^{2+}$ levels resulting in the fusion of the lysosome with the plasma membrane and the release of its contents into the extracellular space [25]. See the review by Wiederanders and colleagues for comprehensive discussion of cysteine cathepsin processing and proenzyme functions [26]. CTSS release is regulated by several factors including pro-inflammatory cytokines, such as IL-1 $\beta$, TNF- $\alpha$, IL- 4 and IL-13 which have been shown to induce CTSS [27-30]. This may also be relevant in the context of inflammatory disease as CTSS is released from resident and recruited immune cells and inflamed tissue. CTSS has a reactive nucleophilic cysteine (Cys25) within its active site that is sensitive to hydrogen peroxide exposure, with the formation of sulfenic acid and converted to sulfinic acid [31]. This is partially reversed with antioxidant treatment [31]. Cysteine cathepsins require reducing and mildly acidic conditions for optimal activity and proteolytic removal of the propeptide domain in order to become active, which can be achieved autocatalytically or through the action of other proteases, which is facilitated at acidic $\mathrm{pH}$ as found in the endolysosomes [32, 33]. The autocatalytic processing of proform CTSS is regulated by negatively charged molecules such as glycosaminoglycans (GAGs) and polysaccharides including dextran sulfate and by changes in $\mathrm{pH}$ [34-36]. However, it is worth noting that this $\mathrm{pH}$-dependent regulation of cathepsins may be less relevant when discussing CTSS as unlike other members of the lysosomal cathepsin family that require an acidic $\mathrm{pH}$, CTSS has potent endoproteolytic activity at a broad $\mathrm{pH}$ range, which allows CTSS to be proteolytically active at neutral $\mathrm{pH}$ found in the healthy lung [23]. Interactions with ECM components such as GAGs may stabilize or alter cathepsin activity in the extracellular milieu at neutral $\mathrm{pH}$. In addition, secreted CTSS can remain bound to the plasma membrane and has been detected in exosomes [37, 38]. Once secreted, the CTSS proenzyme has a half-life of $1-18 \mathrm{~h}$ depending on the origin of the cell [39]. These factors may help stabilize CTSS activity and protect against inactivation in the extracellular milieu, but may pose an additional hurdle to the development of efficacious CTSS inhibitors.

\section{CTSS functions}

Intracellularly, CTSS is best known for its role in antigen presentation [40, 41]. Upon delivering an antigen into the endolysosomal pathway, the invariant chain (Ii) of MHC class II must be cleaved to form a class IIassociated leupeptin-induced peptide (CLIP) fragment, thereby allowing subsequent exogenous antigen binding [41]. The proteolytic cleavage of Ii is catalyzed by active CTSS and other proteases [41]. The CLIP fragment is then cleaved, translocated to the plasma membrane of the antigen-presenting cell to ultimately activate CD4+ $\mathrm{T}$ cells $[41,42]$. CTSS-mediated cleavage of li is not only important for presentation but also mediates dendritic cell motility [41, 42]. CTSS has also been found to be crucial in regulating toll-like receptor (TLR) 9 signaling. TLR9 recognizes unmethylated CpG DNA and translocates from the endoplasmic reticulum to endolysosomal compartments following stimulation where it can be cleaved at the $\mathrm{N}$ - or $\mathrm{C}$-terminal by CTSS, producing 
fragments that inhibit (solubleTLR9) or act as a functional TLR ectodomain, respectively [43]. In addition, a role for CTSS in alum-induced IL-1 $\beta$ secretion was recently reported [44].

Extracellular cathepsins are involved in matrix remodeling via degradation of abundant structural components in the ECM, such as collagen and elastin [45]. CTSS has potent elastolytic and collagenolytic activities that serve an important role in several biological processes such as tissue remodeling. The ECM structure is organized and maintained through a balance of synthesis and degradation by proteolytic processing, including CTSS [45-47]. This processing may occur both extracellularly and intracellularly, with the degradation of ECM proteins internalized by endocytosis [13, 48]. CTSS also cleaves non-matrix proteins such as cytokines $[49,50]$, chemokines [51] and antimicrobial proteins (AMPs) [52], and can function as a sheddase releasing ectodomains of cell adhesion proteins and membrane receptors [53], thereby modulating their activity. Dysregulated CTSS activity and extracellular localization are associated with a number of pathological conditions that will be discussed within the following section of this review.

\section{Status and function of CTSS in pulmonary diseases}

CTSS is particularly relevant in the context of pulmonary disease due to its ability to exert elastase activity, inactivate airway host defense proteins, induce ECM remodeling and alter mucus production across a wide $\mathrm{pH}$ range. Respiratory acidosis or alkalosis, characterized by altered partial pressure of $\mathrm{CO}_{2}$ in arterial blood due to altered alveolar ventilation and consequent insufficient elimination of $\mathrm{CO}_{2}$ from the blood, frequently occurs in several pulmonary diseases, such as bronchopneumonia (acidic), asthma (acidic), COPD (acidic), anemia (basic), pulmonary embolism (basic) and adult respiratory syndrome (basic). Therefore, altered $\mathrm{pH}$ is observed in diseases compared to the normal lung, which has a conservative range of $\mathrm{pH}$ similar to blood of 7.38-7.43 [54]. Equally, the $\mathrm{pH}$ of the exhaled airway vapor condensate is reported to vary from 6.85 to 7.65 [55]. Additionally, CTSS is expressed in numerous pulmonary cell types including alveolar macrophages, fibroblasts, and epithelial cells [56]. Within this section and in Table 1, we outline pulmonary diseases with altered CTSS levels, the role of CTSS as a biomarker or prognostic indicator, as well as findings from animal models demonstrating a significant role of CTSS in pulmonary diseases.

\section{Chronic obstructive pulmonary disease (COPD)}

COPD, principally caused by exposure to cigarette smoke and air pollution, is currently the third leading cause of death affecting 328 million worldwide and is expected to be the leading cause of death within the next
15 years [95]. Proteases are well known to play an important role in the pathogenesis of COPD [1,9]. Elevated CTSS is observed in lung tissue, bronchoalveolar lavage fluid (BALF) and plasma of COPD patients as well as current smokers with or without COPD [57-59]. Importantly, elevated CTSS activity is observed in COPD [57] and appears to increase with disease severity [58]. As discussed previously, among the proteases associated with lung diseases, CTSS is unique in the sense that it has activity at neutral $\mathrm{pH}$, i.e. it could be active within the lung and may contribute to disease initiation. This suggests that elevated CTSS could be one of the first insults in COPD development $[54,56]$. Only $15-20 \%$ of smokers develop COPD, thereby suggesting that genetic, environmental or other as yet unknown factors contribute to the pathogenesis of COPD [96]. In addition, genetic polymorphisms of Ctss have been linked to a higher risk for COPD [97]. Therapeutic inhibition or genetic knockdown of CTSS reduced inflammation, epithelial apoptosis and lung damage in an IFN $\gamma$-induced model of emphysema [98]. A negative feedback loop may exist in COPD, where cysteine cathepsins degrade SLPI [69], a key pulmonary host defense protein and NE inhibitor, which in turn may interfere with the ability of SLPI to inhibit IFN $\gamma$-induced CTSS [57]. One of the most important environmental risk factors of COPD, cigarette smoking, increases the level of CTSS via multiple mechanisms including inhibition of protein phosphatase 2A (PP2A), which in turn increases CTSS expression and activity [99, 100]. Recently, we demonstrated that Ctss deficient mice were resistant to smoke-induced loss of lung function and that restoration of PP2A activation inhibited smoke-induced increases in CTSS expression and loss of lung function [99]. Interestingly, decreased PP2A was also detected in neutrophils from patients with A1AT deficiency, which is associated with COPD pathogenesis [100]. Cigarette smoke also activates the P2X7 receptor in bronchial epithelial cells, which leads to higher CTSS levels [58]. Elevated CTSS levels in BALF correspond to disease severity based on the GOLD staging of COPD in active smokers, and negatively correlate with $\mathrm{FEV}_{1} / \mathrm{FVC}$ and $\mathrm{DLCO} \%[58,101]$. It remains to be determined whether CTSS plays a role in ecigarette associated pulmonary inflammation and damage [102-104]. Breath condensate $\mathrm{pH}$ is lower in patients with COPD and bronchiectasis compared to control subjects [105], which could further influence CTSS activity. Recently, Wartenberg and colleagues demonstrated that pro-CTSS is resistant to cigarette smoke extract inhibition of autocatalytic maturation despite an increase of carbonylation [31]; thereby maintaining its activity in the presence of smoke exposure. However, CTSS activity is sensitive to oxidative stress and other components of cigarette smoke [31]. Overall, 


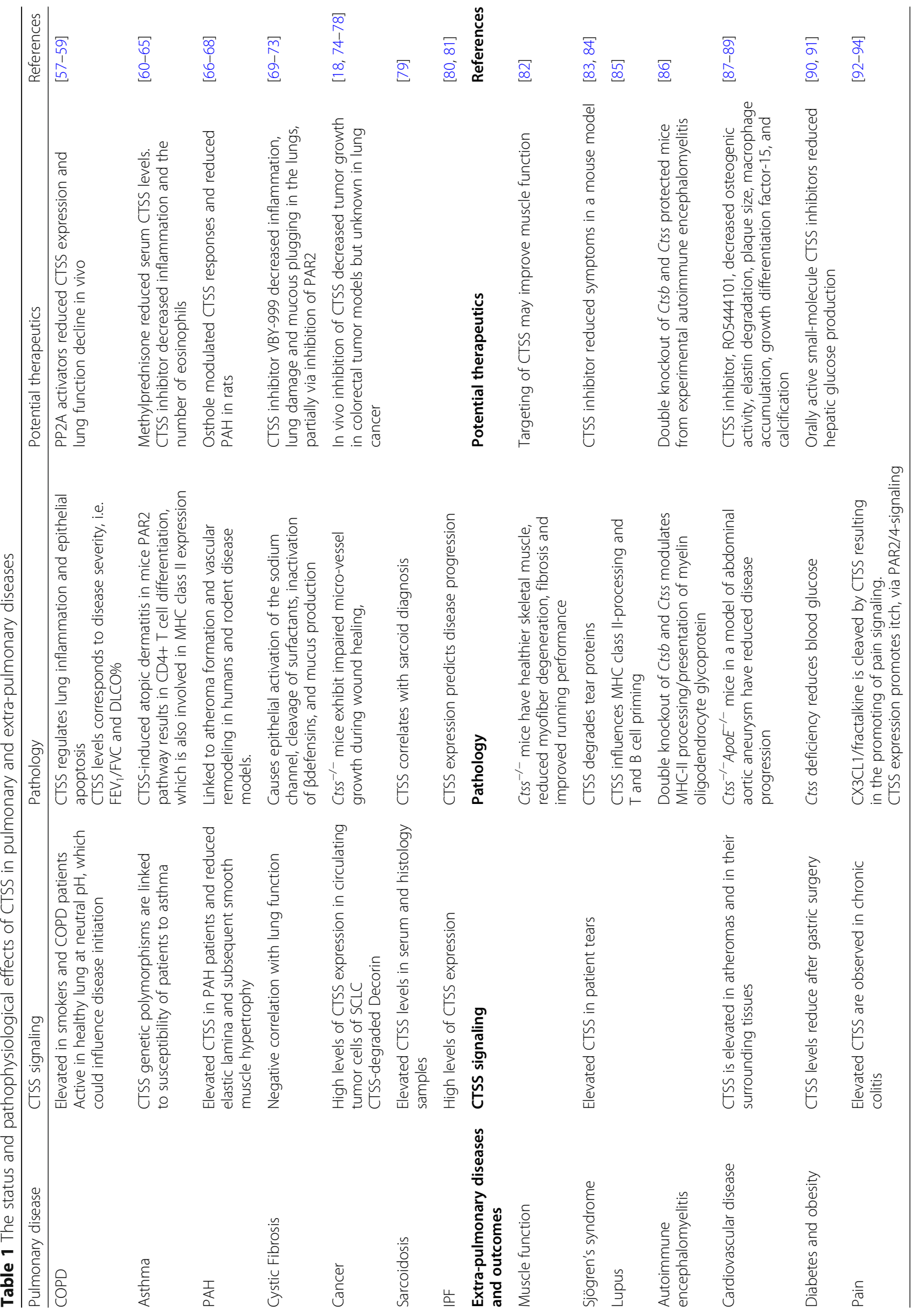




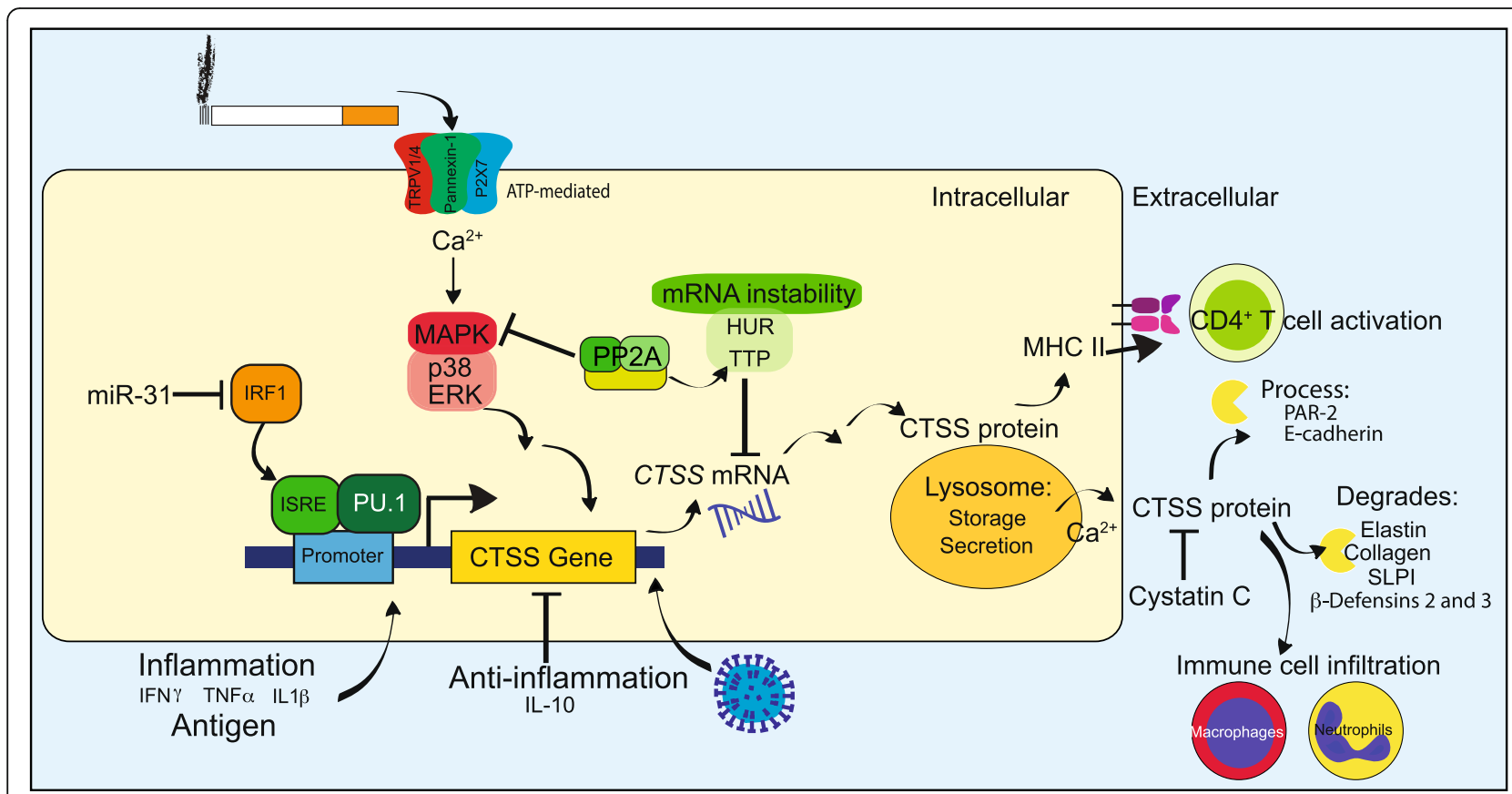

Fig. 1 Mechanisms of CTSS regulation and function

these recent studies demonstrate that CTSS may be an important factor contributing to COPD pathogenesis and severity.

\section{Asthma}

Asthma, one of the most common chronic noncommunicable diseases, has complex genetic and environmental interactions with allergic sensitivity, obesity and cigarette smoking playing a role in its pathogenesis. Corticosteroids are one of the first-line agents for asthma control and for treatment of asthma exacerbation, and response to corticosteroids has a role in prognostic prediction [60]. Asthma patients treated with methylprednisone had lower levels of serum CTSS protein [61]. Similar to COPD, Ctss polymorphisms have also been linked to the susceptibility of patients to asthma [62, 63]. Findings from animal models have also linked CTSS expression with asthma pathogenesis and atopy. Atopic asthma is seen in approximately $50 \%$ of patients with asthma and atopic sensitization may be important in the pathogenesis of severe asthma specifically in childhood onset asthma [106, 107]. CTSS is upregulated in models of eosinophilic inflammation and airway hyperreactivity; IL-13 overexpressing mice, ovalbumin (OVA)-induced allergy model, and mice sensitized with Aspergillus fumigatus antigen [108, 109]. Knockout of Ctss or prophylactic administration of a CTSS inhibitor resulted in decreased airway inflammation and BALF eosinophil counts compared to controls in OVA challenged mice [64]. In addition, prophylactic CTSS inhibitor treatment reduced OVA-induced mucus obstruction in the airways [64] suggesting a possible therapeutic role for prophylactic CTSS inhibitor treatment in patients with asthma. These findings may be secondary to alterations in MHC class II-Ii processing and subsequent peptide loading [110]. CTSS induced itch in human skin and atopic dermatitis in mice via activation of protease-activated receptor (PAR)-2 and -4 [65, 92]. In mice, activation of PAR2 induced dendritic cell maturation and subsequent $\mathrm{CD} 4^{+} \mathrm{T}$ cell differentiation leading to increased dermal inflammation and chronic scratching behavior $[65,92]$. Finally, the $\mathrm{pH}$ of exhaled airway vapor condensate is significantly lower in patients with acute asthma ( $\mathrm{pH}$ 5.23) than in control subjects $(\mathrm{pH}$ 7.65) [55]. This favors the proteolytic activities of cathepsins, including CTSS. Therefore, CTSS may be linked to inflammation, atopy and susceptibility to asthma and dermatitis.

\section{Pulmonary arterial hypertension (PAH)}

Pulmonary arterial hypertension (PAH) is a progressive disease of the lung vascular system characterised by vascular remodelling and narrowing of the blood vessels, resulting in increased vascular resistance and right heart failure [111]. PAH can be idiopathic, genetic or associated with drug and toxin exposures or medical conditions such as COPD [112] and CF [113]. Dysfunctional acid-base transport function is suggested to induce clinically relevant changes in blood pressure and could contribute to hypertension development [114]. Increased 
CTSS and degradation of elastic laminae were observed in the lungs of patients with idiopathic PAH and elevated CTSS activity in pulmonary arterial smooth muscle cells (PASMC) from the monocrotaline (MCT)induced PAH rat model [115]. Administration of a CTSS inhibitor reduced MCT-induced CTSS levels and activity with concomitant preservation of the integrity of elastic laminae of the pulmonary arteries [115]. Inhibiting CTSS reduced PASMC proliferation, migration and reactive oxygen species (ROS) production, which are among the earliest pathobiological features of vascular remodelling, suggesting that CTSS plays a role in the pathogenesis of PAH $[66,67,115]$. In agreement with previous work, peroxisome proliferator-activated receptor (PPAR)- $\gamma$ was identified as an important regulator of CTSS expression in SMCs $[115,116]$. Yao et al. reported that osthole, a novel hypotensive agent purified from the Chinese medical plan Angelica pubescens Maxim, down-regulated MCT-induced CTSS levels while reducing PAH [117].

\section{Cystic fibrosis (CF)}

$\mathrm{CF}$ is a genetic disorder resulting from loss of expression or function of the cystic fibrosis transmembrane conductance regulator chloride channel [118]. CF is a multiorgan disease; however, lung disease is the primary cause of morbidity and mortality in CF patients. Pulmonary manifestations include glandular hyperplasia as well as accumulation of viscous, neutrophil-dominated, mucopurulent debris in the airways which leads to chronic inflammation, recurring infections and lung remodeling as a sequela of altered host immune responses and a protease:antiprotease imbalance $[119,120]$. The first reports of CTSS in the lungs of patients with CF linked CTSS activity to degradation of host AMPs $\beta$ defensins and lactoferrin $[69,121]$. Subsequent work reported increased CTSS expression and activity as a feature of the CF lung in stable patients with CF and also in pediatric patient cohorts, with higher concentrations detectable in lower airways compared to upper airways [70, 122, 123]. Research shows that CTSS plays multiple roles in the pathophysiology of CF including activation of the epithelial sodium channel $(\mathrm{ENaC})$ [71] and cleavage of host defense proteins including surfactants and LL-37 [69, 72, $121,124]$. One of the mechanisms that leads to elevated CTSS levels in CF is the alteration of miRNA-31 expression in bronchial epithelial cells, resulting in elevated CTSS levels via the miR-31/IRF-1/CTSS pathway [70]. Also, increased levels of CTSS measured in BALF from pediatric patients with $C F$ negatively correlated with lung function suggesting that CTSS levels could be used as a possible prognostic biomarker or even a measure of progression of the disease [70]. In a recent study using the $\mathrm{BENaC}$-transgenic mouse model of $\mathrm{CF}$ lung disease, pharmacological or genetic targeting of CTSS decreased inflammation and mucus plugging in the lungs mediated, at least in part, via inhibition of PAR2 suggesting a potential novel therapeutic avenue for CF [73]. Acidic $\mathrm{pH}$ levels are reported on the apical surface liquid of epithelial cells isolated from CF subjects compared to controls [125]. CTSS is also observed on ciliated airway cells and could possibly influence ciliary function [56] but further studies are required. Overall, this research suggests that CTSS could be a significant player in CF lung disease pathogenesis and progression.

\section{Lung Cancer}

Given its ability to remodel the ECM, it is not surprising that there is a vast amount of research on the role of CTSS in cancer [126], however, data specific to lung cancer is relatively limited. Acidic extracellular $\mathrm{pH}$ plays an important role in the cancer microenvironment and contributes to cell invasion and metastasis potential [127]. Serum CTSS is associated with increased cancer mortality [128], and elevated protease expression, including CTSS, is associated with poor prognosis in numerous tumor types [129]. The loci that the CTSS gene is located on chromosome 1q21.2, which is amplified in many cancers [130] and this amplification could contribute to elevated CTSS levels observed in clinical cancer samples, in addition to infiltrating CTSS-rich immune cells. Decorin, a proteoglycan of the interstitial matrix, is degraded by CTSS in lung cancer and may be associated with lung cancer pathology [74]. CTSS proteolytic degradation of nidogen-1, an essential component of the basement membrane and a substrate of CTSS, is strongly associated with non-small cell lung cancer [131]. A recent study showed an increased and exclusive secretion of CTSS in circulating tumor cells of small cell lung cancer, which may predict distant metastasis and targeting CTSS may limit tumor dissemination to distal sites [132]. Interestingly, CTSS has also been linked to breast-to-brain metastasis via processing of the junctional adhesion molecule- $\mathrm{B}$ and subsequent blood-brain barrier transmigration [75].

Recently, CTSS was shown to play an important role in mediating $\mathrm{Ca}^{2+}$ homeostasis by regulating stromal interaction molecule (STIM) 1 trafficking, and inhibition of CTSS resulted in decreased cell migration and invasion [133]. In addition, CTSS promoted pericellular hydrolysis of the ECM within the tumor microenvironment, facilitating endothelial invasion [76]. CTSS is expressed in endothelial cells and may play an important role in angiogenesis; $\mathrm{Ctss}^{-1-}$ mice exhibit impaired microvessel growth during wound healing [18], and CTSS modulated angiogenic peptides involved in microvascular growth $[77,78]$. There is an increasing recognition of the overlapping prevalence of COPD with lung cancer with the presence of COPD increasing the incidence of lung cancer and lung cancer 
mortality [134]. Further work is needed to delineate the role of CTSS in lung cancer and whether there is an association between elevated CTSS in COPD and lung cancer initiation and progression. PP2A activity may represent one such link. As previously mentioned, cigarette smoke increased the level of CTSS via inhibition PP2A, which may function as a tumor suppressor $[99,135]$. Furthermore, cigarette smoke induced the expression of the oncoprotein CIP2A (cancerous inhibitor of PP2A), which down-regulates PP2A activity and enhances proteolytic responses [136], potentially creating a favorable inflammatory micro-environment that may promote tumor formation.

\section{Other pulmonary diseases}

CTSS is also linked to several other pulmonary diseases, including sarcoidosis and IPF. Sarcoidosis a multisystem disease with pulmonary manifestations and recent research has shown that CTSS levels in serum as well as CTSS staining in histology specimens not only correlates with the diagnosis but also with the severity and steroid responsiveness suggesting the potential use of CTSS as a biomarker [79]. Similarly, levels of CTSS have been shown to predict disease progression in patients with IPF [80]. IPF is strongly associated with gastroesophageal reflux disease [137], a condition where acid flow could modulate lung $\mathrm{pH}$ and potentially enhance cathepsin activity. CTSS-degraded decorin is also being investigated as a potential biomarker for fibrotic lung disorders including IPF [81] in addition to lung cancer [74]. Interestingly, the endogenous cathepsin inhibitor, cystatin $C$, is a possible biomarker for IPF [138]. In a mouse model of bronchopulmonary dysplasia, genetic knockdown of Ctss protected against hyperoxia-induced lung injury [139]. $\mathrm{Ctss}^{-/-}$mice displayed improved alveolarization, attenuated macrophage recruitment and fibroproliferative changes, and were protected from growth restriction and alveolar-capillary leak [139].

\section{Extra-pulmonary role of CTSS}

This review focuses on the pulmonary role of CTSS. However, many lung diseases are associated with a high burden of comorbidities [112, 113, 140, 141]. CTSS is expressed by immune cells, smooth muscle cells, epithelial and endothelial cells suggesting that elevated levels of CTSS can circulate in the blood and thus have multiple effects beyond the lungs. Therefore, it is important to briefly discuss the potential impact of CTSS in nonpulmonary disorders often associated with chronic inflammatory lung disease (Table 1). Dysregulated CTSS expression or activity has been linked to several nonpulmonary diseases or outcomes of disease that are frequently observed as pulmonary comorbidities or additional symptoms such as cardiovascular disease and metabolic complications. Here we provide a brief overview of several pieces of data which suggest that CTSS may play a major role in extra-pulmonary disease progression and provide evidence that targeting CTSS may also be a plausible means to treat comorbidities associated with pulmonary diseases.

\section{Skeletal muscle dysfunction}

Muscle fatigue and wasting is frequently observed in pulmonary diseases leading to a decline in pulmonary function, hypoventilation, inefficient cough, hypercapnia, and sleep disorders. CTSS expression is linked to muscle function with $\mathrm{Ctss}^{-/-}$mice having healthier skeletal muscle with reduced myofiber degeneration and fibrosis, and improved running performance in a genetic model of muscular dystrophy [82]. These changes were linked with membrane adhesion complex stability and changes in utrophin, $\beta$-dystroglycan, and integrins. In addition, a muscular dystrophy-like phenotype is induced in skeletal muscle-specific transgenic Ctss overexpressing mice [82]. Hence, increased CTSS expression and activity may play a role in skeletal muscle pathology.

\section{Autoimmune diseases}

Since CTTS responses are triggered by inflammatory stimuli and CTSS deficiency can attenuate MHC class II presentation, many investigators have focused on CTSS as a target in immunological disorders, such as lupus, rheumatoid arthritis, Sjögren's syndrome and encephalomyelitis. CTSS promotes systemic lupus erythematosus by regulating $\mathrm{MHC}$ class II-mediated $\mathrm{T}$ and $\mathrm{B}$ cell priming, germinal center formation and $\mathrm{B}$ cell maturation into plasma cells [85]. Inhibition of CTSS in these models could reduce lupus progression [85] and autoimmunetriggered inflammatory responses in macrophages [142]. Double knockout of Ctsb and Ctss modulates MHC-II processing and presentation of myelin oligodendrocyte glycoprotein, and protects mice from experimental autoimmune encephalomyelitis [86]. Recently, CTSS activity was observed to be elevated in Sjögren's syndrome patient tears, which results in tear protein degradation [83]. Systemic or topical administration of a CTSS inhibitor reduced symptoms in a mouse model of Sjögren's syndrome [84]. Therefore, CTSS appears to play a role in autoimmune responses and represents a potential therapeutic target to treat these diseases in addition to the pulmonary diseases already outlined in this review.

\section{Cardiovascular disease}

In a community-based cohort of elderly men, serum CTSS was associated with increased cardiovascular mortality [128], and CTSS was one of the first cathepsins observed in human atherosclerotic lesions [87]. CTSS is an important player in the pathogenesis of several cardiovascular diseases, such as atherosclerosis, post-myocardial infarction 
remodeling and abdominal aortic aneurysm (AAA) [143-145]. CTSS expression and activity are elevated in atheromas and surrounding tissue, possibly due to the presence of infiltrating immune cells [87], and colocalized with regions of elastin degradation in human coronary plaques [146]. Ctss deficiency reduced plaque formation and disease progression in atherogenic lowdensity lipoprotein receptor $\left(\mathrm{Ldlr}^{-1-}\right)$ mice and apolipoprotein E $\left(A p o E^{-/-}\right)$knockout mice $[146,147]$. Leukocyte Ctss deficiency resulted in smaller plaque necrotic cores, reduced apoptosis, and decreased SMC content and collagen deposition and therefore may be a key player in plaque stability [148]. Elevated CTSS expression was observed in samples from patients with AAA [149], and knockdown of Ctss reduced disease progression in a mouse model of AAA [88]. The selective CTSS inhibitor, RO5444101, decreased osteogenic activity, elastin degradation, plaque size, macrophage accumulation, growth differentiation factor-15, and calcification in a mouse chronic renal disease model [89]. This is important as chronic renal disease accelerates the development of atherosclerosis. Recently, CTSS was also observed to play a significant role in injuryinduced arterial damage in an animal model of stressrelated neointimal hyperplasia [150].

\section{Diabetes}

CTSS may be involved in the early dysregulation of glucose and insulin metabolism as higher serum CTSS was associated with decreased insulin sensitivity and an increased risk for developing diabetes [151]. Several studies have demonstrated a link between CTSS, diabetes and obesity. Ctss deficiency results in a robust reduction in blood glucose, even in diet-induced obesity animal models and aged mice [90]. Interestingly, suppression of CTSS signaling reduced hepatic glucose production without improving insulin sensitivity [90]. Diabetic rats have elevated CTSS, which was reversed with atorvastatin treatment [152]. Elevated circulating CTSS concentrations are associated with metabolic syndrome in overweight and obese adults [153]. Lifestyle changes in moderately overweight subjects resulted in reduced plasma CTSS levels [154]. This is possibly due to elevated levels of CTSS observed in adipose tissue and serum of obese patients. CTSS was identified as an important regulator of PAR2 mediated endothelial dysfunction that promotes microvascular diabetes complications [155].

\section{Other outcomes}

Chronic pain is common in patients with chronic lung disease $[156,157]$ and CTSS activity has been linked to pain in several conditions. The inflammatory chemokine CX3CL1/fractalkine, associated with inflammatory lung diseases [158], is proteolytic cleaved by CTSS resulting in the promotion of pain signaling [50, 159]. Administration of recombinant CTSS into the colonic lumen produces significant nociceptive pain, similar to the pain observed in chronic colitis [160] and elevated levels of CTSS are observed in chronic colitis [93]. Importantly, recent data suggests that circulating CTSS protein levels are associated with increased mortality risk in elderly men and women [128]. Furthermore, CTSS participates in inflammatory processes associated with aging and neurodegeneration [161]. Therefore, CTSS is likely to have a role in aging associated diseases, such as COPD. Therefore, mounting data suggests that CTSS is a significant player in pulmonary and non-pulmonary disease progression that may impact on patient mortality. Research suggest that modulation of CTSS could be beneficial in a range of pulmonary diseases as well as extrapulmonary comorbidities.

\section{Regulation of CTSS}

Whilst CTSS has several important functions within the healthy cell, it is clear that in various pathological states as highlighted in this review, its dysregulation can lead to uncontrolled and damaging proteolytic activity. Therefore, in the physiological state, it is critical that CTSS responses are tightly regulated. This regulation is carried out at multiple levels including expression, zymogen activation, compartmentalization to lysosomes, secretion, and activity [13, 161]. Various mechanisms are employed at each of these regulatory levels to maintain cellular homeostasis. Within this section, we will discuss the mechanisms involved at each of these levels and highlight factors that can alter this regulation in the diseased state.

\section{Regulation of expression}

CTSS is regulated at the expression level, both during transcription and post-transcriptionally. Under proinflammatory conditions, expression of Ctss is induced as a result of signaling by cytokines, most notably by IFN $\gamma$ [162]. The Ctss promotor contains a functional IFN-stimulated response element (ISRE) to which the transcription factor IRF-1 binds, inducing CTSS transcription [163]. The expression of CTSS via IRF-1 has also been shown to be regulated by dysregulated miR-31 in CF bronchial epithelial cells [70]. Other transcription factors including PU.1 and PPAR $\gamma$ may also regulate CTSS expression $[115,164]$. Additionally, inflammatory mediators including IL- $1 \beta$ and TNF- $\alpha$ have been shown to induce CTSS expression, whilst the anti-inflammatory cytokine IL-10 inhibits CTSS expression [165]. In addition to these inflammatory mediators, other molecules are also involved in the regulation of CTSS expression. As mentioned previously, PP2A negatively regulates CTSS expression in a COPD model of smoke- 
induced lung injury and in human bronchial epithelial cells and monocyte-derived macrophages [99]. This is highly relevant as PP2A is dysregulated in several inflammatory conditions including COPD, cancer, neurodegenerative and heart disease [166-168]. This may contribute to the upregulation of CTSS in these conditions and provide a possible new therapeutic target for treatment. Interestingly, CTSS expression is also regulated by proteins involved in the maintenance of circadian rhythms. Diurnal regulation of CTSS gene regulation has been observed following the rhythmic expression of the clock genes Period (Per) 1 and Per 2 [169]. This circadian regulation may be disrupted in asthmatics, suggesting a possible role for the dysregulation of circadian rhythms in chronic lung disease [170].

Post-transcriptional regulation of CTSS mRNA includes regulation by the stabilizing RNA-binding proteins human antigen $\mathrm{R}(\mathrm{HuR})$ and tristetraprolin (TTP). HuR binds to the 3' UTR of the CTSS transcript thereby promoting stability of CTSS mRNA in endothelial cells and may contribute to the elevated CTSS levels seen in human atherosclerotic vascular diseases [171]. The availability of HuR binding sites is increased following adenosine-to-inosine RNA editing, a process that is promoted both by inflammatory stimuli [172] and hypoxia [173], providing an additional mechanism for the regulation of CTSS by both of these stimuli. TTP also regulates pro-inflammatory responses through the destabilization of mRNA and has a significant anti-inflammatory effect in the airways $[174,175]$. PP2A, a previously discussed regulator of CTSS expression, enhances TTP destabilization of mRNA providing an additional mechanism for PP2Aassociated regulation of CTSS [176]. Importantly, TTP expression is dysregulated in several diseases [177], which could enhance CTSS levels. Post-transcriptional regulation of CTSS expression by intracellular pathogens has also been demonstrated. Mycobacterium species including $M$. tuberculosis and M. bovis regulate CTSS to promote their intracellular survival. This regulation is mediated, in part, by miRNAs. Specifically, M. bovis induces the upregulation of miR-106b-5p, a miRNA that targets CTSS, in infected cells [178]. Additionally, IL-10 dependent inhibition of CTSS by M. bovis has been observed [179]. Regulation of CTSS provides a mechanism by which Mycobacterium can attenuate MHC class II surface expression and promote immune evasion [180, 181]. Nitrated fatty acids can downregulated CTSS, via S-alkylation of the Cys 25 site [182]. Overall, it appears that regulation of the expression and production of CTSS is regulated by several mechanism, which appear to be cell and tissue specific.

\section{Regulation of activity}

The regulation of cysteine cathepsin activity is carried out by their endogenous inhibitors, cystatins, thyropins, and serpins. Cystatin $\mathrm{C}$ is the most potent endogenous inhibitor of CTSS activity. Cystatin C is a selective protein inhibitor that is constitutively expressed by most cells, it contains a signal peptide that is responsible for its secretion through the cell membrane and as such is also found at high concentrations in extracellular fluids [183]. Cystatin C inhibits CTSS by physically blocking the active site preventing the binding of its substrate. The high extracellular concentrations of cystatin $\mathrm{C}$ allow it to act as an emergency inhibitor to neutralize excessive extracellular proteolytic activity $[45,184]$. In addition to cystatin $\mathrm{C}$, other members of the cystatin family also regulate CTSS including cystatin F [185]. These endogenous inhibitors provide an important regulatory mechanism for CTSS and this is highlighted by the fact that abnormal formation of cystatin $C$, which is a condition known as hereditary cystatin- $\mathrm{C}$ amyloid angiopathy, results in cerebral hemorrhage with amyloidosis [186]. The CTSS:cystatin C ratio is also increased in the plasma of COPD patients compared to healthy controls highlighting the importance of maintaining a protease:antiprotease balance in which the antiprotease levels exceed that of the protease [59].

In addition to endogenous inhibitors, other factors contribute to the regulation of CTSS activity. An important requirement for optimal CTSS activity is for the enzyme to be maintained in a reduced state as oxidation of the active site cysteine renders the enzyme inactive [187]. Therefore, reducing agents such as $\gamma$-Interferoninducible lysosomal thiol reductase (GILT) are required to maintain CTSS in its reduced active state within the highly acidic, and occasionally oxidative, environment in the late endosomal/lysosomal compartment [188]. This regulation may extend beyond the lysosome with the observed secretion of GILT from activated macrophages, which may promote extracellular CTSS activity during inflammation [28]. However, a separate study demonstrated that GILT shortened the half-life of CTSS, resulting in decreased CTSS steady-state protein levels [189]. This suggests that GILT may regulate CTSS activity by reducing the amount of time the enzyme is active. Conversely, the phagosomal NADPH oxidase NOX2, an oxidizing agent, is an effective inhibitor of CTSS activity, possibly acting as a negative feedback regulatory system to prevent excessive protease activity during inflammation [190]. In contrast, ROS promotes the formation of cystatin $\mathrm{C}$ homodimers thereby leading to dissociation of CTSS and cystatin C and a loss of its inhibitory potential. Indeed, increases in ROS in catalase-silenced cells lead to increased CTSS activity [191], whereas maintenance of low intracellular ROS by symbiotic commensals including Bacteroides vulgatus promotes the ability of cystatin C to inhibit CTSS [192]. These opposing effects of reducing and oxidizing agents on CTSS and its endogenous inhibitor cystatin $\mathrm{C}$ highlight the complex interplay involved in maintaining proteolytic 
homeostasis. Interestingly, CTSS is less susceptible to oxidative stress induced by $\mathrm{H}_{2} \mathrm{O}_{2}$ in acidic $\mathrm{pH}$ conditions compared to other cysteine cathepsins [193]. The microbiome has also been shown to directly regulate CTSS activity via the production of small molecule dipeptide aldehydes that target the catalytic cysteines, blocking the active site of CTSS and preventing binding of substrates [194]. As previously discussed, CTSS plays a major role in antigen presentation and loading of the MHC class II molecule. This process is regulated by $\mathrm{p} 41$, a fragment of the MHC class II-associated Ii. p41 had initially been observed to form a complex with CTSL, acting as a competitive inhibitor by reducing its proteolytic activity, and was considered a specific inhibitor of CTSL [195]. More recent studies have demonstrated a weaker but still physiologically relevant inhibition of CTSS activity by the 411 fragment by the same mechanism [196].

CTSS has extracellular and intracellular functions that can influence physiological changes within the lungs and most importantly influence disease pathology (see Fig. 1 for known CTSS signaling). Targeting CTSS represents a potential therapeutic for several pulmonary diseases and their comorbidities. In addition, a number of upstream factors that modulate CTSS expression and/or production have been identified in various cells, tissues and models of disease. However, whether to target CTSS extracellularly or intracellularly requires further investigation and may be the key to unlocking the development of a safe and efficient anti-CTSS therapeutic for patients.

\section{CTSS therapeutic potential}

Due to the involvement of CTSS in the pathogenesis of numerous diseases as highlighted in this review, there has been increasing interest in the inhibition of CTSS as a potential therapeutic target. Clinical trials to date have primarily focused on autoimmune diseases, including psoriasis, Sjogren's syndrome and rheumatoid arthritis. We will discuss currently available CTSS inhibitors and clinical trials undertaken with these therapeutics to date. Additionally, we will examine the potential adverse effects of long-term CTSS inhibition.

\section{Therapeutic inhibition of CTSS}

Several approaches have been utilized as CTSS inhibitors; these include small molecule inhibitors, neutralizing antibodies, recombinant proteins, and modulation of upstream CTSS regulators. Numerous preclinical studies have demonstrated beneficial effects in various disease models through the use of small-molecule inhibitors to target CTSS [48, 64, 73, 197, 198]. Small-molecule inhibitors are competitive inhibitors that block the enzyme's active site preventing substrate binding. These small molecules are selected from large libraries of natural and synthetic compounds, typically with structures similar to known protease substrates, and screened for their inhibitory activity against CTSS [199]. To date, clinical trials have mostly relied on the use of these small molecule inhibitors to target CTSS due to their high selectivity and oral bioavailability [200]. In addition to these small molecule inhibitors, other therapeutic agents could be utilized to target CTSS expression and activity. Neutralizing antibodies raised against CTSS are a promising therapeutic option. Preclinical studies of the anti-CTSS antibody Fsn0503 have shown potential benefits, demonstrated by in vitro and in vivo models of colorectal carcinoma [76, 201, 202]. However, no clinical studies have yet been undertaken that include anti-CTSS antibodies. Additionally, recombinant CTSS propeptide has been used as a potent inhibitor of CTSS [203]. Both these antibody-based and protein-based therapies specifically target secreted CTSS. This could potentially help negate adverse effects associated with intracellular CTSS inhibition, namely, the blocking of MHC class II loading and subsequent cell-mediated immune responses $[85,142]$. As an alternative to the direct targeting of CTSS, therapeutic agents that target regulators of CTSS expression or activity, as discussed in the previous sections, may have therapeutic potential. Increased production or instillation of the endogenous CTSS inhibitor cystatin C is an example of this alternative therapeutic. Indeed, preclinical studies have shown beneficial effects of the overexpression of cystatin $\mathrm{C}$ in a model of fibrosarcoma lung metastasis $[204,205]$. While recombinant cystatin $C$ therapy has not yet been investigated, treatment with recombinant cystatin from Schistosoma japonicum improved outcomes in 2,4,6Trinitrobenzenesulfonic acid-induced murine model of colitis [206], highlighting the potential for similar therapies involving recombinant cystatin C. Alternatively, the targeting of other CTSS regulators including PP2A, IFNy or IL-6 has shown positive outcomes in initial preclinical studies [207-210].

\section{Clinical trials to date}

Many phase I and II clinical trials were undertaken to assess the safety, dosing, and efficacy of CTSS inhibitors in a variety of diseases [211-223]. Of these 13 studies, six have studied safety and tolerability in healthy volunteers and seven have examined efficacy in psoriasis, rheumatoid arthritis, coeliac disease, and Sjogren's syndrome. These studies have all used small molecule inhibitors of CTSS, namely RO5459072, LY3000328, RWJ445380, VBY-036 and VBY-891, all potent, selective and orally bioavailable compounds [224, 225]. These molecules have demonstrated good safety profiles but variable efficacy in improving disease outcomes. Initial trials launched by Celera in 2005 using the inhibitor CRA028129 were discontinued following phase I clinical trials [226]. This was followed by phase IIa trials in rheumatoid arthritis and psoriasis with RWJ-445380, 
which were discontinued due to poor efficacy. RO5459072 passed a phase I trial in patients with coeliac disease, however, subsequent trials in patients with Sjogren's syndrome showed no change in primary outcome measures. To date, there are no CTSS inhibitors that have become clinically available, primarily due to poor efficacy during phase II clinical trials. However, a phase II trial is currently underway with RO5459072 in psoriasis patients [124]. Given the remit of this review, it would be expected to address clinical trials undertaken to examine the efficacy of CTSS inhibitors in pulmonary disease, however, no such trials have been carried out despite promising preclinical data. Interestingly, a previous phase I dose-escalation study with the CTSS inhibitor LY3000328 noted that while there was an initial decrease in CTSS activity this is followed by a more prolonged period of increased CTSS concentration [225]. This effect was also observed following in vitro inhibition with the broad spectrum cathepsin inhibitor E-64 and recombinant cystatin $C$ [227]. This highlights a potential feedback loop that maintains CTSS activity by stabilizing the CTSS protein following inhibition but we must be mindful of possible risks when utilizing broad range CTS inhibitors such as E-64 and recombinant cystatin C, such as possible modulation of MHCII processing and antigen presentation. Whether this has contributed to poor efficacy in phase II trials of CTSS inhibitors is unclear, however, a better understanding of these feedback mechanisms will be important to progress development of effective CTSS inhibitor-based therapies.

\section{Potential adverse effects}

Clinical trials to date have shown that CTSS inhibitors are, in general, well-tolerated by patients and healthy volunteers. However, several minor adverse events have been noted including, nausea, headache, rash, pruritus, urticaria and increased respiratory tract infection rates in a small percentage of participants. A potential side effect associated with the inhibition of intracellular CTSS is the inhibition of MHC class II loading and subsequent decrease in adaptive immune responses. Inhibition of CTSS leads to decreased MHC class II expression on the surface of macrophages, monocytes and $\mathrm{B}$ cells and reduced expansion and activation of CD4+ T cells as well as suppressed B cell maturation to plasma cells [85, 142]. While this may have a beneficial effect in the treatment of autoimmune conditions such as lupus or rheumatoid arthritis, in conditions associated with infection, including pulmonary conditions such as $\mathrm{CF}$, there is a risk that this could hinder the body's ability to appropriately detect and respond to these infectious agents. This may have contributed to the increased respiratory tract infection rates observed in some participants and to the lack of trials in patients with pulmonary disease. However, we have previously demonstrated that E-64 administration to mice infected with respiratory syncytial virus reduced pulmonary symptoms and aided in viral clearance [228]. Therapies that specifically target extracellular CTSS, such as antibody or protein-based therapies, may be of greater benefit for these conditions. More generally, off-target effects are an issue with cathepsin inhibitors due to high homology between proteases in the family. This has been most notable in the development of CTSK inhibitors [229, 230]. However, X-ray crystallography has provided a more detailed understanding of the structure of the protease active sites allowing the development of more selective cathepsin inhibitors and mitigating the potential side effects of offtarget inhibition [41].

\section{Conclusions}

CTSS has extracellular and intracellular functions that can influence many physiological changes within the lungs and most importantly impact disease pathology. A number of studies suggest that CTSS has potential as a prognostic biomarker, for example, as a surrogate marker of lung disease progression. Targeting CTSS represents a potential therapeutic treatment for several pulmonary diseases and their comorbidities. Recent studies suggest that targeting CTSS may improve several symptoms of pulmonary diseases, such as mucus production, inflammation responses and lung function as observed in animal models of CF [73] and COPD [58, 99]. Improving our understanding of the CTSS degradome is essential to better understand the pathophysiological role of CTSS in health and disease. Importantly, the long-term impact of inhibiting CTSS extracellularly or intracellularly within the lung and systemically requires further investigation.

\section{Abbreviations}

CTSS: Cathepsin S; CF: Cystic fibrosis; COPD: Chronic obstructive pulmonary disease; IPF: Idiopathic pulmonary fibrosis; NE: Neutrophil elastase; A1AT: a1antitrypsin; SLPI: Secretory leukoprotease inhibitor; ECM: Extracellular matrix; MHC: Major histocompatibility complex; GAGs: Glycosaminoglycans;

CLIP: Class II-associated leupeptin-induced peptide; AMP: sAntimicrobial proteins; BALF: Bronchoalveolar lavage fluid; PP2A: Protein phosphatase 2A; OVA: Ovalbumin; PAR: Protease-activated receptor; PAH: Pulmonary arterial hypertension; PASMC: Pulmonary arterial smooth muscle cells;

MCT: Monocrotaline; ROS: Reactive oxygen species; PPAR: Peroxisome proliferator-activated receptor; ENaC: Epithelial sodium channel; STIM: Stromal interaction molecule; CIP2A: Cancerous inhibitor of PP2A; AAA: Abdominal aortic aneurysm; Ldlr: Low-density lipoprotein receptor; ApoE: Apolipoprotein E; ISRE: IFN-stimulated response element; Per: Period; HuR: Human antigen R; TTP: Tristetraprolin; GILT: $\gamma$-Interferon-inducible lysosomal thiol reductase; $\mathrm{H}_{2} \mathrm{O}_{2}$ : Hydrogen peroxide

\section{Acknowledgements}

The authors would like to thank the patients who participated in this study.

\section{Authors' contributions}

S.N., C.T., S.W. and P.G conceived and designed the outline of the review. R.B., S.N., A.L., G.S., Z.E., R.K., C.T., S.W. and P.G. draft the manuscript for important intellectual content. The author(s) read and approved the final manuscript. 


\section{Funding}

This work was supported by grants made available to P.G. (Flight Attendant Medical Research Institute (CIA160005) and the Alpha-1 Foundation (614218), Medical Research Council (MR/P022847/1 C.T./S.W.), Rosetrees Trust (A2450 C.T./S.W.), and the Cystic Fibrosis Foundation (WELDON18G0).

\section{Availability of data and materials}

Not applicable.

\section{Ethics approval and consent to participate}

Not applicable.

\section{Consent for publication}

Not applicable.

\section{Competing interests}

The authors declare that they have no competing interests.

\section{Author details}

${ }^{1}$ Airway Innate Immunity Research (AiiR) Group, Wellcome-Wolfson Institute for Experimental Medicine, School of Medicine, Dentistry and Biomedical Sciences, Queen's University Belfast, Belfast, Northern Ireland, UK. 'Division of Pulmonary \& Critical Care Medicine, Department of Medicine, State University of New York Downstate Medical Centre, Brooklyn, NY, USA. ${ }^{3}$ Department of Cell Biology, State University of New York Downstate Medical Centre, Brooklyn, NY, USA

\section{Received: 3 March 2020 Accepted: 1 May 2020}

\section{Published online: 12 May 2020}

\section{References}

1. Lomas DA. Does protease-Antiprotease imbalance explain chronic obstructive pulmonary disease? Ann Am Thorac Soc. 2016;13(Suppl 2):S130-7.

2. Patel S, Homaei A, El-Seedi HR, Akhtar N. Cathepsins: proteases that are vital for survival but can also be fatal. Biomed Pharmacother. 2018;105:526-32.

3. Garcia-Touchard A, Henry TD, Sangiorgi G, Spagnoli LG, Mauriello A Conover C, Schwartz RS. Extracellular proteases in atherosclerosis and restenosis. Arterioscler Thromb Vasc Biol. 2005:25:1119-27.

4. Taggart C, Mall MA, Lalmanach G, Cataldo D, Ludwig A, Janciauskiene S, Heath N, Meiners S, Overall CM, Schultz C, et al. Protean proteases: at the cutting edge of lung diseases. Eur Respir J. 2017;49(2):1501200.

5. Leiberman J. Letter: familial variation of leukocyte lysosomal protease and serum alpha 1-antitrypsin as determinants in chronic obstructive pulmonary diseases. Am Rev Respir Dis. 1973;108:1019-20.

6. Vogelmeier C, Hubbard RC, Fells GA, Schnebli HP, Thompson RC, Fritz H, Crystal RG. Anti-neutrophil elastase defense of the normal human respiratory epithelial surface provided by the secretory leukoprotease inhibitor. J Clin Invest. 1991;87:482-8.

7. Wiedow O, Schroder JM, Gregory H, Young JA, Christophers E. Elafin: an elastase-specific inhibitor of human skin. Purification, characterization, and complete amino acid sequence. J Biol Chem. 1990;265:14791-5.

8. Twigg MS, Brockbank S, Lowry P, FitzGerald SP, Taggart C, Weldon S. The role of serine proteases and Antiproteases in the cystic fibrosis lung. Mediat Inflamm. 2015:2015:293053.

9. Abboud RT, Vimalanathan S. Pathogenesis of COPD. Part I. the role of protease-antiprotease imbalance in emphysema. Int J Tuberc Lung Dis. 2008;12:361-7

10. Crisford H, Sapey E, Stockley RA. Proteinase 3; a potential target in chronic obstructive pulmonary disease and other chronic inflammatory diseases. Respir Res. 2018;19:180.

11. Kirschke H, Schmidt I, Wiederanders B. Cathepsin S. the cysteine proteinase from bovine lymphoid tissue is distinct from cathepsin L (EC 3.4.22.15). Biochem J. 1986;240:455-9.

12. Villadangos JA, Riese RJ, Peters C, Chapman HA, Ploegh HL. Degradation of mouse invariant chain: roles of cathepsins $S$ and $D$ and the influence of major histocompatibility complex polymorphism. J Exp Med. 1997;186:549-60.

13. Turk V, Stoka V, Vasiljeva O, Renko M, Sun T, Turk B, Turk D. Cysteine cathepsins: from structure, function and regulation to new frontiers. Biochim Biophys Acta. 1824;2012:68-88.
14. Turk B, Turk D, Turk V. Lysosomal cysteine proteases: more than scavengers. Biochim Biophys Acta. 2000;1477:98-111.

15. Bromme D, Nallaseth FS, Turk B. Production and activation of recombinant papain-like cysteine proteases. Methods. 2004:32:199-206.

16. Rossi A, Deveraux Q, Turk B, Sali A. Comprehensive search for cysteine cathepsins in the human genome. Biol Chem. 2004:385:363-72.

17. Veilleux A, Black WC, Gauthier JY, Mellon C, Percival MD, Tawa P, Falgueyret JP. Probing cathepsin S activity in whole blood by the activity-based probe BIL-DMK: cellular distribution in human leukocyte populations and evidence of diurnal modulation. Anal Biochem. 2011;411:43-9.

18. Shi GP, Sukhova GK, Kuzuya M, Ye Q, Du J, Zhang Y, Pan JH, Lu ML, Cheng $X W$, Iguchi $A$, et al. Deficiency of the cysteine protease cathepsin S impairs microvessel growth. Circ Res. 2003;92:493-500.

19. Shi GP, Sukhova GK, Grubb A, Ducharme A, Rhode LH, Lee RT, Ridker PM, Libby P, Chapman HA. Cystatin C deficiency in human atherosclerosis and aortic aneurysms. J Clin Invest. 1999;104:1191-7.

20. Gupta S, Singh RK, Dastidar S, Ray A. Cysteine cathepsin S as an immunomodulatory target: present and future trends. Expert Opin Ther Targets. 2008;12:291-9.

21. Oei E, Kalb T, Beuria P, Allez M, Nakazawa A, Azuma M, Timony M, Stuart Z, Chen $\mathrm{H}$, Sperber K. Accessory cell function of airway epithelial cells. Am J Physiol Lung Cell Mol Physiol. 2004;287:L318-31.

22. Shi GP, Munger JS, Meara JP, Rich DH, Chapman HA. Molecular cloning and expression of human alveolar macrophage cathepsin S, an elastinolytic cysteine protease. J Biol Chem. 1992;267:7258-62.

23. Kirschke H, Wiederanders B, Bromme D, Rinne A. Cathepsin S from bovine spleen. Purification, distribution, intracellular localization and action on proteins. Biochem J. 1989;264:467-73.

24. Wiederanders B, Bromme D, Kirschke $H$, von Figura K, Schmidt B, Peters C. Phylogenetic conservation of cysteine proteinases. Cloning and expression of a cDNA coding for human cathepsin S. J Biol Chem. 1992;267:13708-13.

25. Rodriguez A, Webster P, Ortego J, Andrews NW. Lysosomes behave as Ca2+ -regulated exocytic vesicles in fibroblasts and epithelial cells. J Cell Biol. 1997;137:93-104.

26. Wiederanders B, Kaulmann G, Schilling K. Functions of propeptide parts in cysteine proteases. Curr Protein Pept Sci. 2003;4:309-26.

27. Caglic D, Turk B, Repnik U, Kosec G, Vasiljeva O, Turk V, Jedeszko C, Sloane BF, Miniejew C, Kindermann M, et al. The proinflammatory cytokines interleukin-1 a and tumor necrosis factor a promote the expression and secretion of proteolytically active cathepsin $\mathrm{S}$ from human chondrocytes. Biol Chem. 2013:394:307-16.

28. Lackman RL, Jamieson AM, Griffith JM, Geuze H, Cresswell P. Innate immune recognition triggers secretion of lysosomal enzymes by macrophages. Traffic. 2007:8:1179-89.

29. Yan D, Wang HW, Bowman RL, Joyce JA. STAT3 and STAT6 signaling pathways synergize to promote Cathepsin secretion from macrophages via IRE1alpha activation. Cell Rep. 2016:16:2914-27.

30. Zheng T, Zhu Z, Wang Z, Homer RJ, Ma B, Riese RJ Jr, Chapman HA Jr, Shapiro SD, Elias JA. Inducible targeting of IL-13 to the adult lung causes matrix metalloproteinase- and cathepsin-dependent emphysema. J Clin Invest. 2000;106:1081-93.

31. Wartenberg $M$, Andrault PM, Saidi A, Bigot $P$, Nadal-Desbarats $L$, Lecaille $F$, Lalmanach $\mathrm{G}$. Oxidation of cathepsin $\mathrm{S}$ by major chemicals of cigarette smoke. Free Radic Biol Med. 2020;150:53-65.

32. Maubach G, Schilling K, Rommerskirch W, Wenz I, Schultz JE, Weber E, Wiederanders B. The inhibition of cathepsin S by its propeptide--specificity and mechanism of action. Eur J Biochem. 1997:250:745-50.

33. Mach L, Mort JS, Glossl J. Maturation of human procathepsin B. proenzyme activation and proteolytic processing of the precursor to the mature proteinase, in vitro, are primarily unimolecular processes. J Biol Chem. 1994; 269:13030-5.

34. Vasiljeva $O$, Dolinar $M$, Pungerčar JR, Turk V, Turk B. Recombinant human procathepsin $\mathrm{S}$ is capable of autocatalytic processing at neutral $\mathrm{pH}$ in the presence of glycosaminoglycans. FEBS Lett. 2005;579:1285-90.

35. Kopitar G, Dolinar M, Strukelj B, Pungercar J, Turk V. Folding and activation of human Procathepsin S from inclusion bodies produced in Escherichia coli. Eur J Biochem. 1996;236:558-62.

36. Novinec M, Lenarčič B, Turk B. Cysteine cathepsin activity regulation by glycosaminoglycans. Biomed Res Int. 2014;2014:309718.

37. Potolicchio I, Carven GJ, Xu X Stipp C, Riese RJ, Stern LJ Santambrogio L. Proteomic analysis of microglia-derived exosomes: metabolic role of the 
aminopeptidase CD13 in neuropeptide catabolism. J Immunol. 2005;175: 2237-43.

38. Cheng XW, Kuzuya M, Nakamura K, Di Q, Liu Z, Sasaki T, Kanda S, Jin H, Shi GP, Murohara T, et al. Localization of cysteine protease, cathepsin S, to the surface of vascular smooth muscle cells by association with integrin alphanubeta3. Am J Pathol. 2006;168:685-94.

39. Nissler K, Strubel W, Kreusch S, Rommerskirch W, Weber E, Wiederanders B. The half-life of human procathepsin S. Eur J Biochem. 1999;263:717-25.

40. Ruckrich T, Brandenburg J, Cansier A, Muller M, Stevanovic S, Schilling K, Wiederanders B, Beck A, Melms A, Reich M, et al. Specificity of human cathepsin $\mathrm{S}$ determined by processing of peptide substrates and $\mathrm{MHC}$ class II-associated invariant chain. Biol Chem. 2006;387:1503-11.

41. Wilkinson RD, Williams R, Scott CJ, Burden RE. Cathepsin S: therapeutic, diagnostic, and prognostic potential. Biol Chem. 2015;396:867-82.

42. Zhou Y, Chen H, Liu L, Yu X, Sukhova GK, Yang M, Zhang L, Kyttaris VC, Tsokos GC, Stillman IE, et al. CD74 deficiency mitigates systemic lupus erythematosus-like autoimmunity and pathological findings in mice. J Immunol. 2017;198:2568-77.

43. Manoury B. TLR9 regulation by proteolysis: a friend or a foe. Eur J Immunol. 2011:41:2142-4.

44. Oleszycka E, Moran HBT, Tynan GA, Hearnden CH, Coutts G, Campbell M, Allan SM, Scott CJ, Lavelle EC. IL-1 $a$ and inflammasome-independent IL-1 $\beta$ promote neutrophil infiltration following alum vaccination. FEBS J. 2016;283: 9-24.

45. Vidak E, Javorsek U, Vizovisek M, Turk B. Cysteine Cathepsins and their extracellular roles: shaping the microenvironment. Cells. 2019;8(3):264.

46. Shi GP, Webb AC, Foster KE, Knoll JH, Lemere CA, Munger JS, Chapman HA. Human cathepsin S: chromosomal localization, gene structure, and tissue distribution. J Biol Chem. 1994;269:11530-6.

47. Vizovisek M, Fonovic M, Turk B. Cysteine cathepsins in extracellular matrix remodeling: extracellular matrix degradation and beyond. Matrix Biol. 2019; 75-76:141-59.

48. Baugh M, Black D, Westwood P, Kinghorn E, McGregor K, Bruin J, Hamilton W, Dempster M, Claxton C, Cai J, et al. Therapeutic dosing of an orally active, selective cathepsin $\mathrm{S}$ inhibitor suppresses disease in models of autoimmunity. J Autoimmun. 2011;36:201-9.

49. Ainscough JS, Macleod T, McGonagle D, Brakefield R, Baron JM, Alase A, Wittmann M, Stacey M. Cathepsin S is the major activator of the psoriasisassociated proinflammatory cytokine IL-36gamma. Proc Natl Acad Sci U S A. 2017;114:E2748-e2757.

50. Clark AK, Yip PK, Malcangio M. The liberation of fractalkine in the dorsal horn requires microglial cathepsin S. J Neurosci. 2009;29:6945-54.

51. Repnik U, Starr AE, Overall CM, Turk B. Cysteine Cathepsins activate ELR chemokines and inactivate non-ELR chemokines. J Biol Chem. 2015;290: 13800-11.

52. Lecaille F, Lalmanach G, Andrault PM. Antimicrobial proteins and peptides in human lung diseases: a friend and foe partnership with host proteases. Biochimie. 2016;122:151-68.

53. Sobotic B, Vizovisek M, Vidmar R, Van Damme P, Gocheva V, Joyce JA, Gevaert K, Turk V, Turk B, Fonovic M. Proteomic identification of cysteine Cathepsin substrates shed from the surface of Cancer cells. Mol Cell Proteomics. 2015;14:2213-28.

54. Effros RM, Chinard FP. The in vivo $\mathrm{pH}$ of the extravascular space of the lung. J Clin Invest. 1969:48:1983-96.

55. Hunt JF, Fang K, Malik R, Snyder A, Malhotra N, Platts-Mills TA, Gaston B. Endogenous airway acidification. Implications for asthma pathophysiology. Am J Respir Crit Care Med. 2000;161:694-9.

56. Chapman HA, Riese RJ, Shi GP. Emerging roles for cysteine proteases in human biology. Annu Rev Physiol. 1997;59:63-88.

57. Geraghty P, Greene CM, O'Mahony M, O'Neill SJ, Taggart CC, McElvaney NG. Secretory leucocyte protease inhibitor inhibits interferon-gamma-induced cathepsin S expression. J Biol Chem. 2007;282:33389-95.

58. Andrault PM, Schamberger AC, Chazeirat T, Sizaret D, Renault J, StaabWeijnitz CA, Hennen E, Petit-Courty A, Wartenberg M, Saidi A, et al. Cigarette smoke induces overexpression of active human cathepsin $\mathrm{S}$ in lungs from current smokers with or without COPD. Am J Physiol Lung Cell Mol Physiol. 2019;317:L625-38.

59. Nakajima T, Nakamura H, Owen CA, Yoshida S, Tsuduki K, Chubachi S, Shirahata T, Mashimo S, Nakamura M, Takahashi S, et al. Plasma Cathepsin S and Cathepsin S/cystatin C ratios are potential biomarkers for COPD. Dis Markers. 2016;2016:4093870.
60. Papi A, Brightling C, Pedersen SE, Reddel HK. Asthma. Lancet. 2018;391:783800.

61. Cimerman N, Brguljan PM, Krasovec M, Suskovic S, Kos J. Circadian and concentration profile of cathepsin S in sera from healthy subjects and asthmatic patients. Pflugers Arch. 2001;442:R204-6.

62. Zhou PP, Zhang WY, Li ZF, Chen YR, Kang XC, Jiang YX. Association between SNPs in the promoter region in cathepsin $S$ and risk of asthma in Chinese Han population. Eur Rev Med Pharmacol Sci. 2016;20:2070-6.

63. Li C, Chen Q, Jiang Y, Liu Z. Single nucleotide polymorphisms of cathepsin $\mathrm{S}$ and the risks of asthma attack induced by acaroid mites. Int J Clin Exp Med. 2015;8:1178-87.

64. Deschamps K, Cromlish W, Weicker S, Lamontagne S, Huszar SL, Gauthier JY, Mudgett JS, Guimond A, Romand R, Frossard N, et al. Genetic and pharmacological evaluation of cathepsin $\mathrm{s}$ in a mouse model of asthma. Am J Respir Cell Mol Biol. 2011:45:81-7.

65. Kim N, Bae KB, Kim MO, Yu DH, Kim HJ, Yuh HS, Ji YR, Park SJ, Kim S, Son $\mathrm{KH}$, et al. Overexpression of cathepsin $\mathrm{S}$ induces chronic atopic dermatitis in mice. J Invest Dermatol. 2012;132:1169-76.

66. Vaszar LT, Nishimura T, Storey JD, Zhao G, Qiu D, Faul JL, Pearl RG, Kao PN. Longitudinal transcriptional analysis of developing neointimal vascular occlusion and pulmonary hypertension in rats. Physiol Genomics. 2004;17: 150-6.

67. Hsu HC, Li HH, Lai YJ. Lai the role of smooth muscle Cathepsins in pulmonary arterial hypertension associated with systemic lupus erythematosus. Am J Respir Crit Care Med. 2016;193:2016.

68. Weiss-Sadan T, Gotsman I, Blum G. Cysteine proteases in atherosclerosis. FEBS J. 2017;284:1455-72.

69. Taggart CC, Greene CM, Smith SG, Levine RL, McCray PB Jr, O'Neill S, McElvaney NG. Inactivation of human beta-defensins 2 and 3 by elastolytic cathepsins. J Immunol. 2003;171:931-7.

70. Weldon S, McNally P, McAuley DF, Oglesby IK, Wohlford-Lenane CL, Bartlett JA, Scott CJ, McElvaney NG, Greene CM, McCray PB Jr. Taggart CC: miR-31 dysregulation in cystic fibrosis airways contributes to increased pulmonary cathepsin S production. Am J Respir Crit Care Med. 2014;190:165-74.

71. Haerteis S, Krappitz M, Bertog M, Krappitz A, Baraznenok V, Henderson I, Lindstrom E, Murphy JE, Bunnett NW, Korbmacher C. Proteolytic activation of the epithelial sodium channel $(\mathrm{ENaC})$ by the cysteine protease cathepsinS. Pflugers Arch. 2012;464:353-65.

72. Lecaille F, Naudin C, Sage J, Joulin-Giet A, Courty A, Andrault PM, Veldhuizen RA, Possmayer F, Lalmanach G. Specific cleavage of the lung surfactant protein a by human cathepsin $\mathrm{S}$ may impair its antibacterial properties. Int J Biochem Cell Biol. 2013;45:1701-9.

73. Small DM, Brown RR, Doherty DF, Abladey A, Zhou-Suckow Z, Delaney RJ, Kerrigan L, Dougan CM, Borensztajn KS, Holsinger L, et al. Targeting of cathepsin S reduces cystic fibrosis-like lung disease. Eur Respir J. 2019;53(3): 1801523.

74. Kehlet SN, Bager CL, Willumsen N, Dasgupta B, Brodmerkel C, Curran M, Brix S, Leeming DJ, Karsdal MA. Cathepsin-S degraded decorin are elevated in fibrotic lung disorders - development and biological validation of a new serum biomarker. BMC Pulm Med. 2017;17:110.

75. Sevenich L, Bowman RL, Mason SD, Quail DF, Rapaport F, Elie BT, Brogi E, Brastianos PK, Hahn WC, Holsinger $L$, et al. Analysis of tumour- and stromasupplied proteolytic networks reveals a brain-metastasis-promoting role for cathepsin S. Nat Cell Biol. 2014;16:876-88.

76. Burden RE, Gormley JA, Jaquin TJ, Small DM, Quinn DJ, Hegarty SM, Ward C, Walker B, Johnston JA, Olwill SA, Scott CJ. Antibody-mediated inhibition of cathepsin $\mathrm{S}$ blocks colorectal tumor invasion and angiogenesis. Clin Cancer Res. 2009;15:6042-51.

77. Wang B, Sun J, Kitamoto S, Yang M, Grubb A, Chapman HA, Kalluri R, Shi GP. Cathepsin $S$ controls angiogenesis and tumor growth via matrix-derived angiogenic factors. J Biol Chem. 2006;281:6020-9.

78. Veillard F, Saidi A, Burden RE, Scott CJ, Gillet L, Lecaille F, Lalmanach G. Cysteine cathepsins $S$ and $L$ modulate anti-angiogenic activities of human endostatin. J Biol Chem. 2011;286:37158-67.

79. Hiroyuki Tanaka EY, Asai N, Yokoi T, Nishimura M, Nakao H, Yoneda M, Ohtsuka Y, Konno S, Yamada N. Cathepsin S, a new serum biomarker of sarcoidosis discovered by transcriptome analysis of alveolar macrophages. Sarcoidosis Vasc Diffuse Lung Dis. 2019;36(2):141-7.

80. Ashley SL, Xia M, Murray S, O'Dwyer DN, Grant E, White ES, Flaherty KR, Martinez FJ, Moore BB. Six-SOMAmer index relating to immune, protease 
and Angiogenic functions predicts progression in IPF. PLoS One. 2016;11: e0159878.

81. Nikaido T, Tanino Y, Wang X, Sato Y, Togawa R, Kikuchi M, Misa K, Saito K, Fukuhara N, Kawamata T, et al. Serum decorin is a potential prognostic biomarker in patients with acute exacerbation of idiopathic pulmonary fibrosis. J Thorac Dis. 2018;10:5346-58.

82. Tjondrokoesoemo A, Schips TG, Sargent MA, Vanhoutte D, Kanisicak O, Prasad V, Lin SC, Maillet M, Molkentin JD. Cathepsin S contributes to the pathogenesis of muscular dystrophy in mice. J Biol Chem. 2016;291: 9920-8.

83. Edman MC, Janga SR, Meng Z, Bechtold M, Chen AF, Kim C, Naman L, Sarma A, Teekappanavar N, Kim AY, et al. Increased Cathepsin S activity associated with decreased protease inhibitory capacity contributes to altered tear proteins in Sjogren's syndrome patients. Sci Rep. 2018;8:11044

84. Klinngam W, Janga SR, Lee C, Ju Y, Yarber F, Shah M, Guo H, Wang D, MacKay JA, Edman MC, Hamm-Alvarez SF. Inhibition of Cathepsin S reduces lacrimal gland inflammation and increases tear flow in a mouse model of Sjogren's syndrome. Sci Rep. 2019;9:9559.

85. Rupanagudi KV, Kulkarni OP, Lichtnekert J, Darisipudi MN, Mulay SR, Schott B, Gruner S, Haap W, Hartmann G, Anders HJ. Cathepsin S inhibition suppresses systemic lupus erythematosus and lupus nephritis because cathepsin S is essential for MHC class II-mediated CD4 T cell and B cell priming. Ann Rheum Dis. 2015;74:452-63.

86. Allan ER, Yates RM. Redundancy between cysteine Cathepsins in murine experimental autoimmune encephalomyelitis. PLoS One. 2015; 10:e0128945.

87. Sukhova GK, Shi GP, Simon DI, Chapman HA, Libby P. Expression of the elastolytic cathepsins $S$ and $\mathrm{K}$ in human atheroma and regulation of their production in smooth muscle cells. J Clin Invest. 1998;102:576-83.

88. Qin Y, Cao X, Guo J, Zhang Y, Pan L, Zhang H, Li H, Tang C, Du J, Shi GP. Deficiency of cathepsin $S$ attenuates angiotensin II-induced abdominal aortic aneurysm formation in apolipoprotein E-deficient mice. Cardiovasc Res. 2012;96:401-10.

89. Figueiredo JL, Aikawa M, Zheng C, Aaron J, Lax L, Libby P, de Lima Filho JL, Gruener S, Fingerle J, Haap W, et al. Selective cathepsin S inhibition attenuates atherosclerosis in apolipoprotein E-deficient mice with chronic renal disease. Am J Pathol. 2015;185:1156-66.

90. Lafarge JC, Pini M, Pelloux V, Orasanu G, Hartmann G, Venteclef N, Sulpice T, Shi GP, Clement K, Guerre-Millo M. Cathepsin S inhibition lowers blood glucose levels in mice. Diabetologia. 2014;57:1674-83.

91. Naour N, Rouault C, Fellahi S, Lavoie ME, Poitou C, Keophiphath M, Eberle D, Shoelson S, Rizkalla S, Bastard JP, et al. Cathepsins in human obesity: changes in energy balance predominantly affect cathepsin $\mathrm{s}$ in adipose tissue and in circulation. J Clin Endocrinol Metab. 2010;95:1861-8.

92. Reddy VB, Shimada SG, Sikand P, Lamotte RH, Lerner EA. Cathepsin S elicits itch and signals via protease-activated receptors. J Invest Dermatol. 2010; 130:1468-70.

93. Jimenez-Vargas NN, Pattison LA, Zhao P, Lieu T, Latorre R, Jensen DD, Castro J, Aurelio L, Le GT, Flynn B, et al. Protease-activated receptor-2 in endosomes signals persistent pain of irritable bowel syndrome. Proc Natl Acad Sci U S A. 2018;115:E7438-47.

94. Elmariah SB, Reddy VB, Lerner EA. Cathepsin S signals via PAR2 and generates a novel tethered ligand receptor agonist. PLoS One. 2014;9:e99702.

95. Quaderi SA, Hurst JR. The unmet global burden of COPD. Glob Health Epidemiol Genom. 2018;3:e4.

96. Bosse Y. Genetics of chronic obstructive pulmonary disease: a succinct review, future avenues and prospective clinical applications. Pharmacogenomics. 2009;10:655-67.

97. Gao SL, Wang YH, Li CY, Yang LW, Zou BA, Chen ZG, Yao WM, Song ZQ Cheng JF, Lin ZY, Liu G. A highly significant association between Cathepsin $S$ gene polymorphisms rs12068264 and chronic obstructive pulmonary disease susceptibility in Han Chinese population. Biosci Rep. 2018;38(4): BSR20180410.

98. Zheng T, Kang MJ, Crothers K, Zhu Z, Liu W, Lee CG, Rabach LA, Chapman HA, Homer RJ, Aldous D, et al. Role of cathepsin S-dependent epithelial cell apoptosis in IFN-gamma-induced alveolar remodeling and pulmonary emphysema. J Immunol. 2005;174:8106-15.

99. Doherty DF, Nath S, Poon J, Foronjy RF, Ohlmeyer M, Dabo AJ, Salathe M, Birrell $M$, Belvisi $M$, Baumlin N, et al. Protein phosphatase 2A reduces cigarette smoke-induced Cathepsin S and loss of lung function. Am J Respir Crit Care Med. 2019;200:51-62.
100. Geraghty P, Eden E, Pillai M, Campos M, McElvaney NG. Foronjy RF: alpha 1antitrypsin activates protein phosphatase $2 \mathrm{~A}$ to counter lung inflammatory responses. Am J Respir Crit Care Med. 2014;190:1229-42.

101. Wu KY, Zhu Z, Wang Y, Yin SJ, Li GY, Kong ZB, Liu Y, Li H, Song S. Liu H: [the association between Cathepsin $S$ and pulmonary function and $C T$ phenotypes in patients with chronic obstructive pulmonary disease]. Zhonghua Jie He He Hu Xi Za Zhi. 2019;42:372-7.

102. Scott A, Lugg ST, Aldridge K, Lewis KE, Bowden A, Mahida RY, Grudzinska FS, Dosanjh D, Parekh D, Foronjy R, et al. Pro-inflammatory effects of ecigarette vapour condensate on human alveolar macrophages. Thorax. 2018;73:1161-9.

103. Glynos C, Bibli SI, Katsaounou P, Pavlidou A, Magkou C, Karavana V, Topouzis S, Kalomenidis I, Zakynthinos S, Papapetropoulos A. Comparison of the effects of e-cigarette vapor with cigarette smoke on lung function and inflammation in mice. Am J Physiol Lung Cell Mol Physiol. 2018;315:L662-1672.

104. Garcia-Arcos I, Geraghty P, Baumlin N, Campos M, Dabo AJ, Jundi B, Cummins N, Eden E, Grosche A, Salathe M, Foronjy R. Chronic electronic cigarette exposure in mice induces features of COPD in a nicotinedependent manner. Thorax. 2016;71:1119-29.

105. Kostikas K, Papatheodorou G, Ganas K, Psathakis K, Panagou P, Loukides S. $\mathrm{pH}$ in expired breath condensate of patients with inflammatory airway diseases. Am J Respir Crit Care Med. 2002;165:1364-70.

106. Pearce N, Pekkanen J, Beasley R. How much asthma is really attributable to atopy? Thorax. 1999;54:268-72.

107. Arasi S, Porcaro F, Cutrera R, Fiocchi AG. Severe asthma and allergy: a pediatric perspective. Front Pediatr. 2019;7:28.

108. Fajardo I, Svensson L, Bucht A, Pejler G. Increased levels of hypoxia-sensitive proteins in allergic airway inflammation. Am J Respir Crit Care Med. 2004; 170:477-84.

109. Lewis CC, Yang JY, Huang X, Banerjee SK, Blackburn MR, Baluk P, McDonald DM, Blackwell TS, Nagabhushanam V, Peters W, et al. Disease-specific gene expression profiling in multiple models of lung disease. Am J Respir Crit Care Med. 2008;177:376-87.

110. Riese RJ, Mitchell RN, Villadangos JA, Shi GP, Palmer JT, Karp ER, De Sanctis GT, Ploegh HL, Chapman HA. Cathepsin S activity regulates antigen presentation and immunity. J Clin Invest. 1998;101:2351-63.

111. Rubin LJ. Primary pulmonary hypertension. N Engl J Med. 1997;336:111-7.

112. Cavailles A, Brinchault-Rabin G, Dixmier A, Goupil F, Gut-Gobert C, Marchand-Adam S, Meurice JC, Morel H, Person-Tacnet C, Leroyer C, Diot P. Comorbidities of COPD. Eur Respir Rev. 2013;22:454-75.

113. Ronan NJ, Elborn JS, Plant BJ. Current and emerging comorbidities in cystic fibrosis. Presse Med. 2017;46:e125-38.

114. Boedtkjer E, Aalkjaer C. Disturbed acid-base transport: an emerging cause of hypertension. Front Physiol. 2013:4:388.

115. Chang CJ, Hsu HC, Ho WJ, Chang GJ, Pang JS, Chen WJ, Huang CC, Lai YJ. Cathepsin $\mathrm{S}$ promotes the development of pulmonary arterial hypertension. Am J Physiol Lung Cell Mol Physiol. 2019;317:L1-L13.

116. Hamblin M, Chang L, Zhang H, Yang K, Zhang J, Chen YE. Vascular smooth muscle cell peroxisome proliferator-activated receptor-gamma deletion promotes abdominal aortic aneurysms. J Vasc Surg. 2010;52: 984-93.

117. Yao L, Yang Y, He G, Ou C, Wang L, Liu K. Global proteomics deciphered novel-function of Osthole against pulmonary arterial hypertension. Sci Rep. 2018;8:5556

118. Evans TI, Joo NS, Keiser NW, Yan Z, Tyler SR, Xie W, Zhang Y, Hsiao JJ, Cho $\mathrm{HJ}$, Wright ME, et al. Glandular proteome identifies Antiprotease cystatin C as a critical modulator of airway hydration and clearance. Am J Respir Cell Mol Biol. 2016;54:469-81.

119. Engelhardt JF, Yankaskas JR, Ernst SA, Yang Y, Marino CR, Boucher RC, Cohn $J A$, Wilson JM. Submucosal glands are the predominant site of CFTR expression in the human bronchus. Nat Genet. 1992;2:240-8.

120. Sagel SD, Sontag MK, Wagener JS, Kapsner RK, Osberg I, Accurso FJ. Induced sputum inflammatory measures correlate with lung function in children with cystic fibrosis. J Pediatr. 2002;141:811-7.

121. Rogan MP, Taggart CC, Greene CM, Murphy PG, O'Neill SJ, McElvaney NG. Loss of microbicidal activity and increased formation of biofilm due to decreased lactoferrin activity in patients with cystic fibrosis. J Infect Dis. 2004;190:1245-53.

122. Martin SL, Moffitt KL, McDowell A, Greenan C, Bright-Thomas RJ, Jones AM, Webb AK, Elborn JS. Association of airway cathepsin B and S with inflammation in cystic fibrosis. Pediatr Pulmonol. 2010;45:860-8. 
123. Hentschel J, Fischer N, Janhsen WK, Markert UR, Lehmann T, Sonnemann J, Boer K, Pfister W, Hipler UC, Mainz JG. Protease-antiprotease imbalances differ between cystic fibrosis patients' upper and lower airway secretions. J Cyst Fibros. 2015;14:324-33.

124. Andrault PM, Samsonov SA, Weber G, Coquet L, Nazmi K, Bolscher JG, Lalmanach AC, Jouenne T, Bromme D, Pisabarro MT, et al. Antimicrobial peptide $\mathrm{LL}-37$ is both a substrate of Cathepsins $\mathrm{S}$ and $\mathrm{K}$ and a selective inhibitor of Cathepsin L. Biochemistry. 2015;54:2785-98.

125. Coakley RD, Grubb BR, Paradiso AM, Gatzy JT, Johnson LG, Kreda SM, O'Neal WK, Boucher RC. Abnormal surface liquid $\mathrm{pH}$ regulation by cultured cystic fibrosis bronchial epithelium. Proc Natl Acad Sci U S A. 2003;100:16083-8.

126. Zhang L, Wang $\mathrm{H}, \mathrm{Xu}$ J. Cathepsin $\mathrm{S}$ as a cancer target. Neoplasma. 2015;62: $16-26$.

127. Sutoo S, Maeda T, Suzuki A, Kato Y. Adaptation to chronic acidic extracellular pH elicits a sustained increase in lung cancer cell invasion and metastasis. Clin Exp Metastasis. 2020;37:133-44.

128. Jobs E, Ingelsson E, Riserus U, Nerpin E, Jobs M, Sundstrom J, Basu S, Larsson A, Lind L, Arnlov J. Association between serum cathepsin $S$ and mortality in older adults. JAMA. 2011;306:1113-21.

129. Mason SD, Joyce JA. Proteolytic networks in cancer. Trends Cell Biol. 2011; 21:228-37.

130. Beroukhim R, Mermel CH, Porter D, Wei G, Raychaudhuri S, Donovan J, Barretina J, Boehm JS, Dobson J, Urashima M, et al. The landscape of somatic copy-number alteration across human cancers. Nature. 2010;463: 899-905.

131. Willumsen N, Bager CL, Leeming DJ, Bay-Jensen AC, Karsdal MA. Nidogen-1 degraded by Cathepsin $\mathrm{S}$ can be quantified in serum and is associated with non-Small cell lung Cancer. Neoplasia. 2017;19:271-8.

132. Rath B, Klameth L, Plangger A, Hochmair M, Ulsperger E, Huk I, Zeillinger R, Hamilton G. Expression of proteolytic enzymes by Small cell lung Cancer circulating tumor cell lines. Cancers (Basel). 2019;11(1):114.

133. Lin HH, Chen SJ, Shen MR, Huang YT, Hsieh HP, Lin SY, Lin CC, Chang WW, Chang JY. Lysosomal cysteine protease cathepsin $S$ is involved in cancer cell motility by regulating store-operated $\mathrm{ca}(2+)$ entry. Biochim Biophys Acta Mol Cell Res. 2019;1866:118517.

134. Houghton AM. Mechanistic links between COPD and lung cancer. Nat Rev Cancer. 2013;13:233-45.

135. Nader CP, Cidem A, Verrills NM, Ammit AJ. Protein phosphatase 2A (PP2A): a key phosphatase in the progression of chronic obstructive pulmonary disease (COPD) to lung cancer. Respir Res. 2019;20:222.

136. Nath S, Ohlmeyer M, Salathe MA, Poon J, Baumlin N, Foronjy RF, Geraghty P. Chronic cigarette smoke exposure subdues PP2A activity by enhancing expression of the oncogene CIP2A. Am J Respir Cell Mol Biol. 2018;59:695-705.

137. Raghu G, Freudenberger TD, Yang S, Curtis JR, Spada C, Hayes J, Sillery JK, Pope CE 2nd, Pellegrini CA. High prevalence of abnormal acid gastrooesophageal reflux in idiopathic pulmonary fibrosis. Eur Respir J. 2006;27: 136-42.

138. Kasabova M, Joulin-Giet A, Lecaille F, Saidi A, Marchand-Adam S, Lalmanach G. Human cystatin C: a new biomarker of idiopathic pulmonary fibrosis? Proteomics Clin Appl. 2014:8:447-53.

139. Hirakawa H, Pierce RA, Bingol-Karakoc G, Karaaslan C, Weng M, Shi GP, Saad A, Weber E, Mariani TJ, Starcher B, et al. Cathepsin S deficiency confers protection from neonatal hyperoxia-induced lung injury. Am J Respir Crit Care Med. 2007;176:778-85.

140. Schwarzkopf L, Witt S, Waelscher J, Polke M, Kreuter M. Associations between comorbidities, their treatment and survival in patients with interstitial lung diseases - a claims data analysis. Respir Res. 2018;19:73.

141. Chetty U, McLean G, Morrison D, Agur K, Guthrie B, Mercer SW. Chronic obstructive pulmonary disease and comorbidities: a large cross-sectional study in primary care. Br J Gen Pract. 2017;67:e321-8.

142. Thanei S, Theron M, Silva AP, Reis B, Branco L, Schirmbeck L, Kolb FA, Haap W, Schindler T, Trendelenburg M. Cathepsin S inhibition suppresses autoimmune-triggered inflammatory responses in macrophages. Biochem Pharmacol. 2017;146:151-64.

143. Chen $H$, Wang J, Xiang MX, Lin Y, He A, Jin CN, Guan J, Sukhova GK, Libby $P$, Wang JA, Shi GP. Cathepsin S-mediated fibroblast trans-differentiation contributes to left ventricular remodelling after myocardial infarction. Cardiovasc Res. 2013;100:84-94.

144. Liu CL, Guo J, Zhang X, Sukhova GK, Libby P, Shi GP. Cysteine protease cathepsins in cardiovascular disease: from basic research to clinical trials. Nat Rev Cardiol. 2018;15:351-70.
145. Lai CH, Chang JY, Wang KC, Lee FT, Wu HL, Cheng TL. Pharmacological inhibition of Cathepsin $\mathrm{S}$ suppresses abdominal aortic aneurysm in mice. Eur J Vasc Endovasc Surg. 2020.

146. Rodgers KJ, Watkins DJ, Miller AL, Chan PY, Karanam S, Brissette WH, Long CJ, Jackson CL. Destabilizing role of cathepsin S in murine atherosclerotic plaques. Arterioscler Thromb Vasc Biol. 2006;26:851-6.

147. Sukhova GK, Zhang Y, Pan JH, Wada Y, Yamamoto T, Naito M, Kodama T, Tsimikas S, Witztum JL, Lu ML, et al. Deficiency of cathepsin S reduces atherosclerosis in LDL receptor-deficient mice. J Clin Invest. 2003;111:897906.

148. de Nooijer R, Bot I, von der Thusen JH, Leeuwenburgh MA, Overkleeft HS, Kraaijeveld AO, Dorland R, van Santbrink PJ, van Heiningen SH, Westra MM, et al. Leukocyte cathepsin $\mathrm{S}$ is a potent regulator of both cell and matrix turnover in advanced atherosclerosis. Arterioscler Thromb Vasc Biol. 2009;29: 188-94.

149. Lohoefer F, Reeps C, Lipp C, Rudelius M, Zimmermann A, Ockert S, Eckstein $\mathrm{HH}$, Pelisek J. Histopathological analysis of cellular localization of cathepsins in abdominal aortic aneurysm wall. Int J Exp Pathol. 2012;93:252-8.

150. Wang H, Meng X, Piao L, Inoue A, Xu W, Yu C, Nakamura K, Hu L, Sasaki T, Wu H, et al. Cathepsin S deficiency mitigated chronic stress-related Neointimal hyperplasia in mice. J Am Heart Assoc. 2019;8:e011994.

151. Jobs E, Riserus U, Ingelsson E, Sundstrom J, Jobs M, Nerpin E, Iggman D, Basu S, Larsson A, Lind L, Arnlov J. Serum cathepsin S is associated with decreased insulin sensitivity and the development of type 2 diabetes in a community-based cohort of elderly men. Diabetes Care. 2013;36:163-5.

152. Xu L, Feng B, Wang H, Li X. Multiple statistical methods for assessing differential gene expression in microarray data of diabetic model rats to predict the molecular mechanism of atorvastatin on anti-atherogenesis. Exp Clin Endocrinol Diabetes. 2013;121:272-9.

153. Chen L, Lu B, Yang Y, Zhang W, Wang X, Zhou H, Wen J, Yang Z, Hu R. Elevated circulating cathepsin $S$ levels are associated with metabolic syndrome in overweight and obese individuals. Diabetes Metab Res Rev. 2019;35:e3117.

154. Larsson A, Svensson MB, Ronquist $G$, Akerfeldt T. Life style intervention in moderately overweight individuals is associated with decreased levels of cathepsins L and S in plasma. Ann Clin Lab Sci. 2014;44:283-5.

155. Kumar Vr S, Darisipudi MN, Steiger S, Devarapu SK, Tato M, Kukarni OP, Mulay SR, Thomasova D, Popper B, Demleitner J, et al. Cathepsin S cleavage of protease-activated Receptor-2 on endothelial cells promotes microvascular diabetes complications. J Am Soc Nephrol. 2016;27:1635-49.

156. Lee AL, Rawlings S, Bennett KA, Armstrong D. Pain and its clinical associations in individuals with cystic fibrosis: a systematic review. Chron Respir Dis. 2016;13:102-17.

157. van Dam van Isselt EF, Groenewegen-Sipkema KH, Spruit-van Eijk M, Chavannes NH, de Waal MW, Janssen DJ, Achterberg WP. Pain in patients with COPD: a systematic review and meta-analysis. BMJ Open. 2014;4: e005898.

158. Zhang J, Patel JM. Role of the CX3CL1-CX3CR1 axis in chronic inflammatory lung diseases. Int J Clin Exp Med. 2010;3:233-44.

159. Clark AK, Yip PK, Grist J, Gentry C, Staniland AA, Marchand F, Dehvari M, Wotherspoon G, Winter J, Ullah J, et al. Inhibition of spinal microglial cathepsin $S$ for the reversal of neuropathic pain. Proc Natl Acad Sci U S A. 2007;104:10655-60.

160. Cattaruzza F, Lyo V, Jones E, Pham D, Hawkins J, Kirkwood K, Valdez-Morales E, Ibeakanma C, Vanner SJ, Bogyo M, Bunnett NW. Cathepsin S is activated during colitis and causes visceral hyperalgesia by a PAR2-dependent mechanism in mice. Gastroenterology. 1864-1874;2011(141):e1861-3.

161. Stoka V, Turk V, Turk B. Lysosomal cathepsins and their regulation in aging and neurodegeneration. Ageing Res Rev. 2016;32:22-37.

162. Schwarz G, Boehncke W-HH, Braun M, Schröter CJ, Burster T, Flad T, Dressel D, Weber E, Schmid H, Kalbacher H. Cathepsin S activity is detectable in human keratinocytes and is selectively upregulated upon stimulation with interferon-gamma. J Invest Dermatol. 2002;119:44-9.

163. Storm van's Gravesande K, Layne MD, Ye Q, Le L, Baron RM, Perrella MA, Santambrogio L, Silverman ES, Riese RJ. IFN regulatory Factor-1 regulates IFN- $\gamma$-dependent Cathepsin S expression. J Immunol. 2002;168:4488-94.

164. Wang Y, Baron RM, Zhu G, Joo M, Christman JW, Silverman ES, Perrella MA, Riese RJ, Cernadas M. PU.1 regulates Cathepsin S expression in professional APCs. J Immunol. 2006;176:275-83.

165. Fiebiger $E$, Meraner $P$, Weber E, Fang IF, Stingl G, Ploegh H, Maurer D. Cytokines regulate proteolysis in major histocompatibility complex class II- 
dependent antigen presentation by dendritic cells. J Exp Med. 2001;193: 881-92.

166. Wallace AM, Hardigan A, Geraghty P, Salim S, Gaffney A, Thankachen J, Arellanos L, D'armiento JM, Foronjy RF. Protein phosphatase 2A regulates innate immune and proteolytic responses to cigarette smoke exposure in the lung. Toxicol Sci. 2012;126:589-99.

167. Sontag E, Luangpirom A, Hladik C, Mudrak I, Ogris E, Speciale S, White CL. Altered expression levels of the protein phosphatase $2 \mathrm{~A} A B a C$ enzyme are associated with Alzheimer disease pathology. J Neuropathol Exp Neurol. 2004;63:287-301.

168. Sangodkar J, Farrington CC, McClinch K, Galsky MD, Kastrinsky DB, Narla G. All roads lead to PP2A: exploiting the therapeutic potential of this phosphatase. FEBS J. 2016;283:1004-24.

169. Hayashi Y, Koyanagi S, Kusunose N, Okada R, Wu Z, Tozaki-Saitoh H, Ukai K, Kohsaka S, Inoue K, Ohdo S, Nakanishi H. The intrinsic microglial molecular clock controls synaptic strength via the circadian expression of cathepsin S. Sci Rep. Sci Rep. 2013;3:2744.

170. Cimerman N, Brguljan PM, Krasovec M, Suskovic S, Kos J, Krašovec M, Šuškovič S, Kos J. Circadian and concentration profile of cathepsin $\mathrm{S}$ in sera from healthy subjects and asthmatic patients. Pflugers Arch. 2001;442:R2046.

171. Stellos K, Gatsiou A, Stamatelopoulos K, Perisic Matic L, John D, Lunella FF, Jaé N, Rossbach O, Amrhein C, Sigala F, et al. Adenosine-to-inosine RNA editing controls cathepsin $\mathrm{S}$ expression in atherosclerosis by enabling HuRmediated post-transcriptional regulation. Nat Med. 2016;22:1140-50.

172. Yang JH, Luo X, Nie Y, Su Y, Zhao Q, Kabir K, Zhang D, Rabinovici R. Widespread inosine-containing mRNA in lymphocytes regulated by ADAR1 in response to inflammation. Immunology. 2003;109:15-23.

173. Nevo-Caspi Y, Amariglio N, Rechavi G, Paret G. A-to-I RNA editing is induced upon hypoxia. Shock. 2011;35:585-9.

174. Ross EA, Smallie T, Ding Q, O'Neil JD, Cunliffe HE, Tang T, Rosner DR, Klevernic I, Morrice NA, Monaco C, et al. Dominant suppression of inflammation via targeted mutation of the mRNA destabilizing protein Tristetraprolin. J Immunol. 2015;195:265-76.

175. Bollmann F, Wu Z, Oelze M, Siuda D, Xia N, Henke J, Daiber A, Li H, Stumpo DJ, Blackshear PJ, et al. Endothelial dysfunction in tristetraprolin-deficient mice is not caused by enhanced tumor necrosis factor-a expression. J Biol Chem. 2014:289:15653-65.

176. Rahman MM, Rumzhum NN, Hansbro PM, Morris JC, Clark AR, Verrills NM, Ammit AJ. Activating protein phosphatase 2A (PP2A) enhances tristetraprolin (TTP) anti-inflammatory function in A549 lung epithelial cells. Cellular Signal. 2016;28:325-34.

177. Nair PM, Starkey MR, Haw TJ, Liu G, Horvat JC, Morris JC, Verrills NM, Clark AR, Ammit AJ, Hansbro PM. Targeting PP2A and proteasome activity ameliorates features of allergic airway disease in mice. Allergy. 2017;72: 1891-903.

178. Pires D, Bernard EM, Pombo JP, Carmo N, Fialho C, Gutierrez MG, Bettencourt P, Anes E. Mycobacterium tuberculosis modulates miR-106b-5p to control Cathepsin $S$ expression resulting in higher pathogen survival and poor T-cell activation. Front Immunol. 2017;8:1819.

179. Sendide K, Deghmane A-E, Pechkovsky D, Av-Gay Y, Talal A, Hmama Z. Mycobacterium bovis BCG attenuates surface expression of mature class II molecules through IL-10-dependent inhibition of Cathepsin S the. J Immunol. 2005;175:5324-32.

180. Baena A, Porcelli SA. Evasion and subversion of antigen presentation by Mycobacterium tuberculosis. Tissue Antigens. 2009;74:189-204.

181. Pai RK, Convery M, Hamilton TA, Boom WH, Harding CV. Inhibition of IFN- $\gamma^{-}$ induced class II Transactivator expression by a 19-kDa lipoprotein from Mycobacterium tuberculosis : a potential mechanism for immune evasion. J Immunol. 2003;171:175-84

182. Reddy AT, Lakshmi SP, Muchumarri RR, Reddy RC. Nitrated fatty acids reverse cigarette smoke-induced alveolar macrophage activation and inhibit protease activity via electrophilic S-alkylation. PLoS One. 2016;11:e0153336.

183. Magister Š, Kos J. Cystatins in immune system. J Cancer. 2013:4:45-56.

184. Fonović M, Turk B. Cysteine cathepsins and extracellular matrix degradation. Biochim Biophys Acta. 2014;1840:2560-70

185. Magister Š, Obermajer N, Mirković B, Švajger U, Renko M, Softić A, Romih R, Colbert JD, Watts C, Kos J. Regulation of cathepsins $S$ and $L$ by cystatin F during maturation of dendritic cells. Eur J Cell Biol. 2012;91:391-401.

186. Ólafsson I, Grubb A. Hereditary cystatin C amyloid angiopathy. Amyloid. 2000;7:70-9.
187. Klomsiri C, Karplus PA, Poole LB. Cysteine-based redox switches in enzymes. Antioxid Redox Signal. 2011;14:1065-77.

188. Balce DR, Allan ERO, McKenna N, Yates RM. $y$-Interferon-inducible lysosomal thiol reductase (GILT) maintains phagosomal proteolysis in alternatively activated macrophages. J Biol Chem. 2014;289:31891-904.

189. Phipps-Yonas H, Semik V, Hastings KT. GILT expression in B cells diminishes cathepsin $\mathrm{S}$ steady-state protein expression and activity. Eur J Immunol. 2013;43:65-74.

190. Xu Y, Lindemann P, Vega-Ramos J, Zhang JG, Villadangos JA. Developmental regulation of synthesis and dimerization of the amyloidogenic protease inhibitor cystatin C in the hematopoietic system. J Biol Chem. 2014;289:9730-40.

191. Tsai JY, Lee MJ, Dah-Tsyr Chang M, Huang H. The effect of catalase on migration and invasion of lung cancer cells by regulating the activities of cathepsin S, L, and K. Exp Cell Res. 2014;323:28-40.

192. Steimle A, Gronbach K, Beifuss B, Schäfer A, Harmening R, Bender A, Maerz JK, Lange A, Michaelis L, Maurer A, et al. Symbiotic gut commensal bacteria act as host cathepsin S activity regulators. J Autoimmun. 2016;75:82-95.

193. Lalmanach G, Saidi A, Bigot P, Chazeirat T, Lecaille F, Wartenberg M. Regulation of the proteolytic activity of cysteine Cathepsins by oxidants. Int J Mol Sci. 2020;21(6):1944.

194. Guo CJ, Chang FY, Wyche TP, Backus KM, Acker TM, Funabashi M, Taketani M, Donia MS, Nayfach S, Pollard KS, et al. Discovery of reactive microbiota-derived metabolites that inhibit host proteases. Cell. 2017; 168:517-526.e518.

195. Ogrinc T, Dolenc I, Ritonja A, Turk V. Purification of the complex of cathepsin $\mathrm{L}$ and the MHC class II-associated invariant chain fragment from human kidney. FEBS Lett. 1993;336:555-9.

196. Mihelič M, Doberšek A, Gunčar G, Turk D. Inhibitory fragment from the p41 form of invariant chain can regulate activity of cysteine cathepsins in antigen presentation. J Biol Chem. 2008;283:14453-60.

197. Saegusa K, Ishimaru N, Yanagi K, Arakaki R, Ogawa K, Saito I, Katunuma N, Hayashi Y. Cathepsin S inhibitor prevents autoantigen presentation and autoimmunity. J Clin Invest. 2002;110:361-9.

198. Xu J, Wang H, Ding K, Lu X, Li T, Wang J, Wang C, Wang J. Inhibition of cathepsin $\mathrm{S}$ produces neuroprotective effects after traumatic brain injury in mice. Mediat Inflamm. 2013;2013:187873.

199. Palermo C, Joyce JA. Cysteine cathepsin proteases as pharmacological targets in cancer. Trends Pharmacol Sci. 2008;29:22-8.

200. Lee-Dutra A, Wiener DK, Sun S. Cathepsin S inhibitors: 2004 - 2010. Expert Opin Ther Pat. 2011;21:311-37.

201. Burden RE, Gormley JA, Kuehn D, Ward C, Kwok HF, Gazdoiu M, McClurg A, Jaquin TJ, Johnston JA, Scott CJ, Olwill SA. Inhibition of Cathepsin S by Fsn0503 enhances the efficacy of chemotherapy in colorectal carcinomas. Biochimie. 2012;94:487-93.

202. Ward C, Kuehn D, Burden RE, Gormley JA, Jaquin TJ, Gazdoiu M, Small D, Bicknell R, Johnston JA, Scott CJ, Olwill SA. Antibody targeting of Cathepsin $\mathrm{S}$ inhibits angiogenesis and synergistically enhances anti-VEGF. PLoS One. 2010:5:e12543.

203. Burden RE, Snoddy P, Buick RJ, Johnston JA, Walker B, Scott CJ. Recombinant cathepsin $\mathrm{S}$ propeptide attenuates cell invasion by inhibition of cathepsin L-like proteases in tumor microenvironment. Mol Cancer Ther. 2008;7:538-47.

204. Kopitz C, Anton M, Gansbacher B, Krüger A. Reduction of experimental human fibrosarcoma lung metastasis in mice by adenovirus-mediated cystatin C overexpression in the host. Cancer Res. 2005;65:8608-12.

205. Sokol JP, Schiemann WP. Cystatin C antagonizes transforming growth factor $\beta$ signaling in normal and cancer cells. Mol Cancer Res. 2004;2:183-95.

206. Wang S, Xie Y, Yang X, Wang X, Yan K, Zhong Z, Wang X, Xu Y, Zhang Y, Liu $F$, Shen J. Therapeutic potential of recombinant cystatin from Schistosoma japonicum in TNBS-induced experimental colitis of mice. Parasit Vectors. 2016:9:6.

207. Hennigan S, Kavanaugh A. Interleukin-6 inhibitors in the treatment of rheumatoid arthritis. Ther Clin Risk Manag. 2008:4:767-75.

208. Skurkovich B, Skurkovich S. Inhibition of IFN-gamma as a method of treatment of various autoimmune diseases, including skin diseases. Ernst Schering Res Found Workshop. 2006;(56):1-27.

209. McClinch K, Avelar RA, Callejas D, Izadmehr S, Wiredja D, Perl A, Sangodkar J, Kastrinsky DB, Schlatzer D, Cooper M, et al. Small-molecule activators of protein phosphatas $2 \mathrm{~A}$ for the treatment of castration-resistant prostate cancer. Cancer Res. 2018;78:2065-80. 
210. Sangodkar J, Perl A, Tohme R, Kiselar J, Kastrinsky DB, Zaware N, Izadmehr S, Mazhar S, Wiredja DD, O'Connor CM, et al. Activation of tumor suppressor protein PP2A inhibits KRAS-driven tumor growth. J Clin Invest. 2017;127:2081-90.

211. McNeely TB, Dealy M, Dripps DJ, Orenstein JM, Eisenberg SP, Wahl SM. Secretory leukocyte protease inhibitor: a human saliva protein exhibiting antihuman immunodeficiency virus 1 activity in vitro. J Clin Invest. 1995;96:456-64.

212. Hosakote YM, Liu T, Castro SM, Garofalo RP, Casola A. Respiratory syncytial virus induces oxidative stress by modulating antioxidant enzymes. Am J Respir Cell Mol Biol. 2009;41:348-57.

213. Chen J, Parsons S, Brautigan DL. Tyrosine phosphorylation of protein phosphatase $2 \mathrm{~A}$ in response to growth stimulation and $\mathrm{V}$-src transformation of fibroblasts. J Biol Chem. 1994;269:7957-62.

214. Barik S, McLean T, Dupuy LC. Phosphorylation of Ser232 directly regulates the transcriptional activity of the P protein of human respiratory syncytial virus: phosphorylation of Ser237 may play an accessory role. Virology. 1995; 213:405-12.

215. Vogl T, Tenbrock K, Ludwig S, Leukert N, Ehrhardt C, van Zoelen MA, Nacken W, Foell D, van der Poll T, Sorg C, Roth J. Mrp8 and Mrp14 are endogenous activators of toll-like receptor 4, promoting lethal, endotoxininduced shock. Nat Med. 2007;13:1042-9.

216. Kelschenbach JL, Saini M, Hadas E, Gu CJ, Chao W, Bentsman G, Hong JP, Hanke T, Sharer LR, Potash MJ, Volsky DJ. Mice chronically infected with chimeric HIV resist peripheral and brain superinfection: a model of protective immunity to HIV. J Neurolmmune Pharmacol. 2012;7:380-7.

217. Hadas E, Borjabad A, Chao W, Saini M, Ichiyama K, Potash MJ, Volsky DJ. Testing antiretroviral drug efficacy in conventional mice infected with chimeric HIV-1. AIDS. 2007;21:905-9.

218. Schonbeck U, Mach F, Libby P. Generation of biologically active IL-1 beta by matrix metalloproteinases: a novel caspase-1-independent pathway of IL-1 beta processing. J Immunol. 1998;161:3340-6.

219. Guma M, Ronacher L, Liu-Bryan R, Takai S, Karin M, Corr M. Caspase 1independent activation of interleukin-1 beta in neutrophil-predominant inflammation. Arthritis Rheum. 2009:60:3642-50.

220. Ramaswamy M, Groskreutz DJ, Look DC. Recognizing the importance of respiratory syncytial virus in chronic obstructive pulmonary disease. COPD. 2009;6:64-75.

221. Tsai SY, Segovia JA, Chang TH, Morris IR, Berton MT, Tessier PA, Tardif MR, Cesaro A, Bose S. DAMP molecule S100A9 acts as a molecular pattern to enhance inflammation during influenza a virus infection: role of DDX21TRIF-TLR4-MyD88 pathway. PLoS Pathog. 2014;10:e1003848.

222. Lee JJ, Jacobsen EA, Ochkur SI, McGarry MP, Condjella RM, Doyle AD, Luo H, Zellner KR, Protheroe CA, Willetts L, et al. Human versus mouse eosinophils: "that which we call an eosinophil, by any other name would stain as red". J Allergy Clin Immunol. 2012;130:572-84.

223. Gringhuis $\mathrm{SI}$, van der Vlist $\mathrm{M}$, van den Berg LM, den Dunnen J, Litjens $\mathrm{M}$, Geijtenbeek TB. HIV-1 exploits innate signaling by TLR8 and DC-SIGN for productive infection of dendritic cells. Nat Immunol. 2010;11:419-26.

224. Theron M, Bentley D, Nagel S, Manchester M, Gerg M, Schindler T, Silva A, Ecabert B, Teixeira P, Perret C, Reis B. Pharmacodynamic monitoring of RO5459072, a small molecule inhibitor of cathepsin S. Front Immunol. 2017:8:806.

225. Payne CD, Deeg MA, Chan M, Tan LH, LaBell ES, Shen T, DeBrota DJ. Pharmacokinetics and pharmacodynamics of the cathepsin S inhibitor, LY3000328, in healthy subjects. Br J Clin Pharmacol. 2014;78:1334-42.

226. Kramer $L$, Turk $D$, Turk $B$. The future of cysteine Cathepsins in disease management. Trends Pharmacol Sci. 2017;38:873-98.

227. Wilder CL, Walton C, Watson V, Stewart FAA, Johnson J, Peyton SR, Payne CK, Odero-Marah V, Platt MO. Differential cathepsin responses to inhibitorinduced feedback: E-64 and cystatin C elevate active cathepsin S and suppress active cathepsin $\mathrm{L}$ in breast cancer cells. Int J Biochem Cell Biol. 2016;79:199-208.

228. Foronjy RF, Taggart CC, Dabo AJ, Weldon S, Cummins N, Geraghty P. Type-I interferons induce lung protease responses following respiratory syncytial virus infection via RIG--like receptors. Mucosal Immunol. 2015;8:161-75.

229. Gall CL, Bonnelye E, Clézardin P. Cathepsin K inhibitors as treatment of bone metastasis. Curr Opin Support Palliat Care. 2008;2:218-22.

230. Brömme D, Lecaille F. Cathepsin K inhibitors for osteoporosis and potential off-target effects. Exp Opin Invest Drugs. 2009;18:585-600.

\section{Publisher's Note}

Springer Nature remains neutral with regard to jurisdictional claims in published maps and institutional affiliations.

Ready to submit your research? Choose BMC and benefit from:

- fast, convenient online submission

- thorough peer review by experienced researchers in your field

- rapid publication on acceptance

- support for research data, including large and complex data types

- gold Open Access which fosters wider collaboration and increased citations

- maximum visibility for your research: over $100 \mathrm{M}$ website views per year

At BMC, research is always in progress.

Learn more biomedcentral.com/submissions 